\title{
ESTIMATED RESOURCES OF NON-LEASED FEDERAL COAL, POWDER RIVER BASIN, MONTANA AND WYOMING
}

By

\author{
V.A. Trent
}

1986

\section{INTRODUCTION}

The 1976 Federal Coal Leasing Amendments Act (P.L. 94-377) and the 1976 Federal Land Policy and Management Act (P.L. 94-579) require that a comprehensive inventory of unleased Federal coal be made available to the public. The U.S. Geological Survey (USGS) responded in fiscal year 1977 by initiating a Coal Resource Occurrence/Coal Development Potential (CRO/CDP) map program to "determine the reserves of unleased Federal coal and to characterize for Federal land-use planning, the relative development potential of each leasable 40 acre tract" (Wayland, 1981, p. 543). The CRO/CDP map reports were to be compiled on 7.5 -minute quadrangles using only publicly available data. Because of the need to meet time limitations of lease negotiations, most of the CRO/CDP work was to be done by consulting firms under contract; however, USGS geologists were to monitor each stage of completion.

For the Powder River Basin (Index map) the CRO/CDP program was officially completed by June 1982 , when 243 of the 7.5-minute quadrangle reports contracted for had been placed on USGS open file. The results are summarized in Trent (1985) and also here in table 1; quadrangles involved are outlined on figure 1. Simultaneous use of table 1 and figure 1 allows the reader to locate and compare the large quantities of unleased, high development potential, strippable Federal coal. Each of the 243 CRO/CDP reports was reviewed prior to entering some of their data into the National Coal Resources Data System (NCRDS).

The CRO/CDP program for the Powder River Basin was restricted to estimating resources of unleased Federally owned coal contained in Tertiary coal beds more than $5 \mathrm{ft}$ thick. Coal on Indian lands was not included in the estimates, and many quadrangles along the east and west margins of the basin (fig. 1) were not included in the CRO/CDP program. However, this report does include estimates of coal resources in seven 7.5-minute quadrangles near Sheridan, Wyo. (fig. 1) that were not included in the CRO/CDP program. USGS reports containing these estimates are listed in table 2 and in the references. Also available from other USGS reports are separate estimates of coal resources in many quadrangles that were included in the CRO/CDP program. These reports, listed in table 3 , are also included in the references.

\section{Acknowledgments}

Nancy K. Teaford, USGS geologist, spent many hours assisting me in compiling the resource estimates, and my special thanks also go to a "Powder River Basin Analysis Team" of USGS geologists, who compiled the resource map (fig. 1). Team members includet Laura Biewick, Carol Connor, John Hardie, Neal Hinrichs, Carol Molnia, Frances Pierce, and Laura Roberts.

\section{GEOGRAPHIC SETTING}

The Powder River Basin is a large northnorthwest-trending topographic and structural basin in northeast Wyoming and southeastern Montana, between the Bighorn Mountains to the west, the Laramie Mountains to the south, and the Black Hills to the east (Index map). Northward, the Powder River Basin is separated from the Williston Basin by the Miles City arch (McGregor, 1972, p. 269). Coalbearing rock underlies about $16,000 \mathrm{mi}^{2}$, of which there are nearly $10,000 \mathrm{mi}^{2}$ in Wyoming and $6,000 \mathrm{mi}^{2}$ in Montana. The northern part of the Powder River Basin includes virtually all of Powder River County and parts of Big Horn, Rosebud, and Custer Counties, Montana; the southern part of the basin includes all of Campbell County, as well as parts of Sheridan, Crook, Weston, Niobrara, Converse, Natrona, and Johnson Counties, Wyoming (Index map). The main drainages are north- and northeast-flowing tributaries of the Yellowstone River-Rosebud Creek, Tongue River, Powder River, and the Little Powder River. The central part of the basin in Wyoming is also traversed by the northeast-trending Belle Fourche River, which is a tributary to the Cheyenne River further eart. The southern part of the basin is drained by streams that join the North Platte River, which then flows eastward to a junction with the Missouri River. The average elevation in the basin is 5,000 ft (McGregor, 1972, p. 270 ).

\section{Land Use and Ownership}

Before 1862, all land in the Powder River Basin was in the public domain, having been acquired by the United States as the result of the Louisiana P rchase in 1803. Congress passed Homestead Acts in 1862, 1909 , and 1916 and other statutes to encourage settlement and convert much of this land to private ownership. Thus, millions of acres of public land were opened to entry and settlement. A homesteader 
retained the surface and mineral rights on his land if he acquired it before 1909. After certain "separation laws" were passed by Congress from 1907 to 1910 , these rights were split, and the Federal government retained the mineral rights on lands sold thereafter. As a result, the Federal government has emerged as the largest holder of mineral rights in the Powder River Basin (U.S. Geological Survey, 1973).

Large acreages in the region, termed school lands, were transferred to state ownership. Specifically, sections 16 and 36 in every township were given to the States, with the stipulation that the income from these lands was to be used to support public education. The States control all surface and mineral rights in these areas.

Another significant land grant was given to the railroads in 1864 as an incentive to expand and open the area to commerce. Under this grant, title to all odd-numbered sections in an area $60 \mathrm{mi}$ on each side of a railroad right-of-way was granted to the railroads traversing the area. Thus, Burlington Northern, Inc. (then Northern Pacific Railroad), shares the mineral rights about equally with the Federal government in part of the northern Powder River Basin around Colstrip, Mont.

Land ownership in the Powder River Basin is divided at present between the Federal government, State governments, the private sector, and the Crow and Northern Cheyenne Indians. Nearly 60 percent of the surface rights in the basin are privately owned, according to estimates using Bureau of Land Managment (BLM) land ownership maps for the region (U.S. Bureau of Land Managment, 1974-77). The Federal government controls about 27.5 percent of the basin, the States have jurisdiction over 7.5 percent, and the Indians own 5 percent. Mineral rights, on the other hand, are divided approximately as follows: 70 percent is controlled by the Federal government, 17.5 percent is privately owned, 7.5 percent is state owned, and 5 percent belongs to the Indians. Until about 10 years ago, Federal coal land could be leased more or less on demand, but currently all Federal coal leasing is on the basis of competitive auctions. All of the leased coal shown on the CRO/CDP reports was leased before competitive auctions were required by law.

About 87 percent of the basin is used for agricultural purposes, and roughly 90 percent of that area is rangeland suited for cattle and sheep grazing (U.S. Bureau of Land Management, 1981, p. 40). What farming there is consists mainly of dryland hay, both grass and alfalfa, or grain. Other land uses include mining, oil and gas production, transportation networks, national forests, Indian reservations, recreation areas, and urban areas.

\section{GEOLOGIC SETTING}

\section{Stratigraphy}

A thick sequence of sedimentary rocks and surficial deposits, whose ages range from Cambrian to Quaternary, unconformably overlie the Precambrian crystalline basement complex in the Powder River Basin. It has been estimated that as much as $18,000 \mathrm{ft}$ of sedimentary rocks overlies the axial trough of the basin adjacent to the Bighorn and Laramie Mountains (McGregor, 1972, p. 269-270). The youngest rocks in the basin are coal-bearing Cretaceous and Tertiary strata. The outline of the Powder River Basin shown on the Index map and figure 1 of this report is at the boundary of the coal-bearing rocks of the Upper Cretaceous Mesaverde Formation (Glass, 1980, F. 99; Keefer, 1974). Many Tertiary coal beds are separated by variable rock sequences, ranging from thin shale beds to strata hundreds of feet thick that change from coarse sandstone or conglomerate to siltstone, claystone, and shale.

Cretaceous coal beds are interbedded in similar types of rock but are generally less than $10 \mathrm{ft}$ thick and much less numerous. Because the Cretaceous coal beds are generally thin and mostly lie very deep in the basin, they are unimportant from a resource standpoint. No estimates of Cretaceous coal resources are presented in the CRO/CDP study.

The thickest and most important coal beds of the Powder River Basin are in the Paleocene Fort Union Formation and the Eocene Wasatch Formation. The Fort Union Formation is a prolific coal-bearing rock unit that ranges from 2,000 to $3,000 \mathrm{ft}$ in thickness (Glass, 1980, p. 104). The thickest and most persistent coal beds are located at the top of the formation, in the 1,500- to 1,800-foot-thick Tcngue River Member. Typically, the Tongue River Member consists of sandstone, siltstone, mudstone, shale, carbonaceous shale, and thick beds of coal (Kent and Berlage, 1980). The middle and lower members of the Fort Union Formation are, respectively, the Lebo Shale and the Tullock Member. The Lebo Shale comprises sandstone, claystone, shale, carbonaceous shale, and thin beds of coal. The Tullock Memter is sandstone and silty shale, carbonaceous shale, anc thin beds of coal (Kent and Berlage, 1980). The coal beds in the two lower members are not thick or widesf nead enough to be considered as important for coal resources (Glass, 1978 , p. 20-21). Coals in the Tongue River Member are best developed in the northerr and eastern parts of the Powder River Basin. Noteable are the 8 to 12 subbituminous coal beds cropping out along the Tongue River valley from Monarch, Wyc. to Decker, Mont. (Law and others, 1979) and in the Birney-Broadus coal field of Montana (Warren, 1959).

This report does not define stratigraphic boundaries in the Powder River Basin because there is considerable controversy about the correlation of coal beds and the position of the boundary between Paleocene and Eocene strata (Glass, 1978, p. 104105). Some coal beds are assigned to different members of the Fort Union Formation because of lateral lithofacies changes. Therefore, with these problems in mind, I will present some properly referenced stratigraphic terminology. The Roland coal bed of Baker (1929) is considered to be the uppermost unit of the Fort Union Formation in some of the northern part of the Powder River Basin (Law and others, 1979; Olive, 1957). The thickest and economically most important coal bed in the Powder River Basin is the Wyodak-Anderson, which is from $\mathbf{5 0}$ to 100 feet thick in large areas. This coal bed, which has burned over many hundreds of acres, has been mapped for more than a hundred miles along the eastern side of the basin. Westward the WycdakAnderson splits into two or more beds, resulting in an expanded coal-bed nomenclature and correlation problems.

The Wasatch Formation, up to $2,000 \mathrm{ft}$ thick and containing as many as eight thick persistent coal beds, overlies the Fort Union Formation. It crops out over much of the central part of the Powder Piver 
Basin, mostly in Wyoming, and usually dips less than $4^{\circ}$ toward the center of the basin. The thickest Wasatch coal is at Lake DeSmet on the west side of the basin north of Buffalo, Wyo. There the Healy coal bed locally exceeds $225 \mathrm{ft}$ in thickness in drill holes (Mapel, 1959); it is the thickest coal bed described in Wyoming and probably in the United States. Another thick coal was found by drilling approximately midway between Buffalo and Gillette, Wyo. This deposit, with a maximum thickness of about $205 \mathrm{ft}$, is termed "Big George" and results from the coalescing of thinner coal beds of the Fort Union Formation (Bion H. Kent, USGS, oral commun., 1982). Generally, Wasatch coals are thickest and most persistent in the western and central parts of the basin (Glass, 1978, p. 21).

\section{Structure}

The Powder River Basin is a broad asymmetrical syncline whose axis trends northnorthwest along its western side adjacent to the Bighorn Mountains (McGregor, 1972, pp. 269-270). In Montana, the structural axis trends northward through the Stroud Creek quadrangle (figure 1, Montana quadrangle 86) which is located in the trough of the basin (Mapel and others, 1978, p. 5). Most central and eastern parts of the Powder River Basin, including much of the area of this report, are situated along the homoclinal east limb of the fold where most beds dip westward at less than $2^{\circ}$ and commonly less than $1^{\circ}$. In general, the Cretaceous rocks on the flanks of the basin dip more steeply than the nearly flat-lying Tertiary strata, except along the west and south flanks where locally Paleocene beds dip as much as $25^{\circ}$ (Glass, 1978, p. 20). Although normal faults displace outcropping rocks in many parts of the basin, faults are relatively rare, except along the western margin particularly in southern Johnson County. Most faults in the Sussex area about $50 \mathrm{mi}$ north of Casper, Wyo. trend northeastward and have maximum apparent vertical displacements of 300 to $400 \mathrm{ft}$.

\section{COAL}

The greatest long-term energy source in the Powder River Basin is immense quantities of lowsulfur subbituminous coal. Coal production from the Powder River Basin leads all other basins in the western United States; it is the principal reason that in 1984 Wyoming ranked third and Montana tenth in the nation after Kentucky (first) and West Virginia (second) in coal output (U.S. Department of Energy, 1985 , p. 7-11). Preliminary coal production figures for 1985 indicate that Wyoming has displaced West Virginia as the second leading coal producing state with a total of 137.8 million short tons (U.S. Department of Energy, 1986, p. 67). There are six coal-fired electric powerplants at four localities in the Powder River Basin, having a total generating capacity of about 1,870 megawatts (Shifflett, 1982). Most coal mined in the Powder River Basin is sent to other steam-powered electric generating plants (Keefer and Schmidt, 1973) in the midwest and south-central United States (U.S. Bureau of Land Management, 1974, v. 1, p. 35). Only a minor part of the basin's coal production is consumed in the Powder River Basin powerplants.

\section{Coal Production}

Huge quantities of low-sulfur subbituminous coal have been strip mined from thick beds in the Powder River Basin of Montana and Wyoming. Annual production of coal from the Powder River Basin has been increasing steadily since the Organization of Petroleum Exporting Countries (OPEC) oil embargo in 1973, and the percentage of total U.S. production from the basin has also increased from 1.8 percent in 1973 to 18.9 percent in 1985 (table 5 ). Most of the increase of nearly 19 million short tons from 1978 to 1979 came from one new mine and expanded production at the other operating mines near Gillette in Campbell County, Wyoming. Campbell County by a wide margin is the first-ranked coal-producing county in the country, having produced 106.8 million short tons of subbituminous coal from 14 surface mines in 1984 (U.S. Department of Energy, 1985, pp. 7-11).

An in-depth study of world coal supply and production has been made by Mr. A.M. Clarke, of the British National Coal Board (written commun., 1983). Briefly, his research suggests that in projectir? coal output for very large basins over long-term time intervals (15-20 years), the rates of production have a momentum of their own. The coal production rates continue on the same gradient regardless of fluctuations caused by ups and downs of business cycles, wars, labor problems, or changes in technology. He also believes that coal is a unique commodity because even though it is undergoing world-wide depletion, its long-term future price trend will be downward.

Future coal production from the Powder River Basin is projected to increase more slowly during the next few years because of a lessening of electric power requirements and business activity. Using the long-term coal production trends shown by takle 5 , I estimate that the total United States coal production will be about 1 billion short tons by 1990 , ard that about 230-250 million short tons of that total will be produced from the Powder River Basin. A more optimistic estimate has been published by Data Resources, Inc., a econometric forecasting sorvice. Coal production from the Powder River Basin is projected by this firm to increase 14.4 percent in 1984 and in 1985, and they estimate that 409 million short tons of coal will be produced from the Powder River Basin in the year 2000 (Coal Week, 1984, p. 3).

\section{Coal Rank and Quality}

Most of the Powder River Basin corls are subbituminous in rank and low in sulfur; Btu valies are relatively low, but the low sulfur content makes the coal a prized fuel because little or no cleaning is required to meet established emission standards. In general, these coals contain less than 0.5 percent sulfur, and ash content ranges from 5 to 8 percent.

Coal rank in the Powder River Basin of Montana ranges from lignite $A$ along the eastern margin of the basin to subbituminous $A$, which predominates to the west (see table 6 for explanation of coal rank). Lignite underlies the northeastern part of the basin in a strip two to three quadrangles wide where the strata were less-deeply buried along the edge of the basin. This rather limited area of lower-rank coal is a southward extension of the Tertiary Fort Union lignite field in North Dakota and Montana (Trumbull, 1960). With few 
exceptions, the coal beds in this part of the basin are low in sulfur (less than 1 percent) and have low to moderate ash contents. Heating values determined from coal samples range from roughly $6,500 \mathrm{Btu} / \mathrm{lb}$ along the eastern side of the basin to about 9,500 $\mathrm{Btu} / \mathrm{lb}$ in the vicinity of Decker, Mont. (Matson and Blumer, 1974, p. 13).

The rank of the thicker and more important coal beds in the Wyoming portion of the Powder River Basin varies from lignite $A$ in the northeast to subbituminous $\mathrm{C}$ or $\mathrm{B}$ over much of the remaining basin area (Glass, 1978 , p. 20). The subbituminous Tertiary coals have as-received moisture contents of 20 to 30 percent (mean value is 26.3 percent) and about equal percentages of volatile matter and fixed carbon. For the coal beds currently being mined in northeastern Wyoming, the sulfur content ranges from 0.45 to 0.6 percent, the mean value being 0.54 percent (Glass, 1978 , p. 8). The ash content for coal sampled from the Wyoming part of the basin ranges from 4.4 to 11.4 percent-the mean value is 7.9 percent. The heat content values for coal samples from this part of the basin range from 7,550 to $8,700 \mathrm{Btu} / \mathrm{lb}$, and the mean value is $8,300 \mathrm{BTU} / \mathrm{lb}$ (all values were determined on an as-received basis) (Glass, 1978, p. 8).

Generally coal beds in the northern Great Plains, including those in the Fort Union Formation of Montana and Wyoming, contain appreciably lesser amounts of most chemical elements of environmental concern than do coal beds in other areas of the United States (Hatch and Swanson, 1977, p. 147). Studies have shown that most Wyoming coals can be washed to reduce their ash contents to within suitable yield limits (Glass, 1978, p. 9). Also, most Wyoming coals are non-agglomerating and may be carbonized in fluidized systems (Glass, 1978, p. 12-13), although the end product-a lump char-is relatively weak.

\section{CRO/CDP PROGRAM SPECIFICATIONS AND PRODUCTS}

Primary objectives of the CRO/CDP map program were to classify and estimate coal resources on 7.5-minute quadrangles, according to tonnage categories of surface-minable coal, deep-minable coal, and in situ gasification coal. Relative development potentials (high, moderate, low) were to be calculated for both surface-mining and in situ gasification, to serve as guides for land-use planning by the BLM, and to help set priorities for leasing.

The Department of the Interior designated the Powder River Basin as one of the first priority areas for the initial resumption of general coal leasing. The Geologic Division of the USGS was one of the initial contractors for the Powder River Basin CRO/CDP program, and USGS geologists began work in 13 quadrangles of the Montana part of the basin (fig. 1).

\section{Reserve base problem}

Two USGS definitions for reserve base are used in this report. When the USGS geologists began work on the 13 quadrangles in Montana at the start of the CRO/CDP program, no formal contract specifications had been set. It was agreed that the reserve base should include subbituminous coal beds 60 in. or more thick that occur at depths to $1,000 \mathrm{ft}$, and that the stripping limit for surface-minable coal be $200 \mathrm{ft}$. These limits conformed to the accepted definition and criteria for the reserve base in standard use at that time, (U.S. Bureau of Mines and U.S. Geological Survey, 1976, p. B5) and now (Wood and others. 1983, pp. 29-30). However, when the USGS contract specialists and monitors later wrote the specifications for the private contractors, they changed the limiting depth criteria for surface-minable coal to $500 \mathrm{ft}$, and the criteria for reserve-base coal to a depth limit of $3,000 \mathrm{ft}$. Hereafter, the latter will be referred to as the reserve base and the former as the standard reserve base. Therefore, the standard reserve base definition applies only to the 13 quadrangle reports in Montana that were mapped by the USGS (fig. 1), while for the remaining $230 \mathrm{CRO} / \mathrm{CDP}$ reports in the Powder River Basin the reserve base is applicable.

\section{Contract specifications}

The coal resources inventoried in this program exist in a wide range of geologic conditions. is that the CRO/CDP maps and estimated resource figures would be consistent, it was necessary to standardize terms and conditions before bids for the work could be called for. USGS field and headquarters personnel had to make many difficult choices, as is evident in this selected list:

- 60 in. minimum coal bed thickness for all mining methods;

- 3,000 ft maximum limit of depth of burial for conventional underground mining methods:

- $200 \mathrm{ft}$ stripping limit for a single coal bed less than $40 \mathrm{ft}$ thick;

- $500 \mathrm{ft}$ stripping limit for thicker beds or multiple beds;

- $0-15^{\circ}$ dip for conventional underground mining methods

- $15-90^{\circ}$ dip for in situ production, except in the Powder River Basin where all dips are ver" low

- 85 percent recovery of coal tonnages for surface mining

- 50 percent recovery of coal tonnages for conventional underground mining methods, but only for a maximum thickness of coal beds of 12 $\mathrm{ft}$

Reliability categories based only on distance from data points are: Measured coal- -0 to $0.25 \mathrm{mi}$; Indicated coal- -0.25 to $0.75 \mathrm{mi}$; and Inferred coal- -0.75 to $3 \mathrm{mi}$ (fig. 2).

\section{Coal Resource Occurrence maps}

Each CRO/CDP report listed in table 4 and the pamphlet Appendix consists of a brief text and a group of maps (the average is about 20) of a 7.5-minute quadrangle. There is a general description of the CRO/CDP program in each text and a summary of the geology for each quadrangle. Included also, in atdition to the classified coal resource tonnages for the quadrangle, are all available quality data for co-l beds underlying the map area and a discussion of the coal development potential. The first of the maps (all have a planimetric township and range base) consists of three plates: plate 1 , the Coal Data Map, showing basic geologic data including mapped coal beds with coal data points (coal thickness measurements) plotted along with mines and prospects, drill holes, and areas of burned coal; plate 2, the Boundary and Coel Data 
Map, showing the area underlain by recoverable coal (the total tonnages of reserve base coal are listed by section), all non-Federal coal land, and the leased coal areas and plate 3 , the Coal Data Sheet, which has a generalized geologic columnar section for the quadrangle, and at least one cross section derived from drill holes and(or) measured sections with the coal beds correlated where possible.

Two to five derivative coal bed maps were then prepared for each coal bed thick enough to be part of the reserve base category (60 in. + ). These derivative maps include coal bed isopachs, structure contours, and overburden isopach and mining ratio maps; two additional maps also show the areal distribution of identified coal resources by section, and the total resources for each coal bed on a strippable and nonstrippable basis.

The coal resources could have been calculated for other areas of interest, such as previously leased Federal and State lands and privately owned coal lands, because the coal resource occurrence maps show coal thickness information for all categories of land ownership except Indian lands. However, for this study only the unleased Federal coal was estimated so that leasing could proceed in approved areas according to a schedule. Before the estimation of coal resources could begin, a USGS monitor met with the contractor to select an applicable stripping limit and a mining recovery factor for each quadrangle, and to decide on any other limiting conditions. Thereafter, the contractor was only concerned with unleased Federal coal in known recoverable coal resource areas (KRCRA) boundaries within the quadrangle.

By definition, all coal that lies within a radius of $0.25 \mathrm{mi}$ of a coal data point (a site where the thickness of coal was measured as shown in fig. 2) was classified as measured coal. The area surrounding the data point within a radius of $0.75 \mathrm{mi}$ and beyond the measured coal area was classified as indicated coal. Lastly, the area around the data point circumscribed by a $3-$ mile radius and beyond the indicated coal was classified as inferred coal. The contractor drew the arcs around the coal data points and the areas made by the intersection of these ares with the known boundary of unleased Federal coal permitted the calculation of measured, indicated, and inferred coal. Then the tonnage of in-place coal was calculated for each of these categories and plotted for each section of land. Separate tabulations were compiled for surfaceminable and deep-minable coal.

\section{Coal Development Potential maps}

Coal development potential maps delineate areas that have high, moderate, and low coal development potential for surface mining, underground mining, and in situ gasification. Arbitrary standards for calculating development potential were devised by USGS personnel and incorporated into the contract specifications.

Coal Development Potential for surface mining.--The CDP for surface-minable coal is based upon the coal bed mining ratio value (MR), where

$$
M R=\frac{\text { cubic yards of overburden }}{\text { short tons of recoverable coal. }}
$$

Where $M R=0$ to 10 the coal development potential is high, if $M R=10$ to 15 the coal development potential is moderate, and if $M R$ is greater than 15 the coal development potential is low. The coal development potential for surface mining is based only on a mining ratio applied to coal $5 \mathrm{ft}$ or more thick to a depth of $500 \mathrm{ft}(200 \mathrm{ft}$ for the 13 quadrangles completed by the USGS geologists in Montana). The coal development potential classification for each tract of land is that of the highest classification of development potential for any one coal bed in the area.

Coal Development Potential for underground mining.--USGS personnel reached the decision that underground coal mining in the Powder River Basin was not economically feasible, mainly berause of exceedingly thick coal beds and dangerous roof conditions, so contractors were not required to calculate the develpment potential for underground mining. For purposes of this report, however, all resources of underground coal that would otherwise be included in the reserve base are arbitrarily assigned a low coal development potential for underground mining.

Coal Development Potential for in situ gasification.--Subsurface coal beds in the Wyoming part of the Powder River Basin were evaluated for in situ gasification development potential on the basis of criteria as follows:

Low development potential relates to: a) a total coal section less than $100 \mathrm{ft}$ thick that lies $1,000 \mathrm{ft}$ to $3,000 \mathrm{ft}$ beneath the surface, or b) a coal bed or coal zone $5 \mathrm{ft}$ or more thick that lies $500 \mathrm{ft}$ to $1,000 \mathrm{ft}$ beneath the surface; and to inclined beds whose dip is $15^{\circ}$ to $35^{\circ}$.

Moderate development potential is assigned to a total coal section from 100 to $200 \mathrm{ft}$ thick and buried from 1,000 to $3,000 \mathrm{ft}$ beneath the surface; and to inclined beds whose dip is $35^{\circ}$ to $90^{\circ}$.

High development potential involves $270 \mathrm{ft}$ or more of total coal thickness buried from 1,000 to $3,000 \mathrm{ft}$; and the degree of dip of inclined beds is not applicable.

CDPs for in situ gasificaton of subsurface coel beds in the Montana part of the basin were not calculrted.

Land-use planners, for whom the end products were designed, may find the data plates and darivative maps and reports generally instructive. The ["SGS will use the products as the starting point for further data collection and synthesis and for re-interpretation in light of new publicly available or proprietary information.

\section{RESOURCE ESTIMATES OF UNLEASED FEDERAL COAL}

Table 1 summarizes estimated resources of nonleased Federally-owned coal in the 243 quedrangles included in the CRO/CDP map program for the Powder River Basin, Montana and Wyoming. The grand total of these estimated reserve base coal resourc?s (down to $3,000 \mathrm{ft}$ depth of overburden and for beds $5 \mathrm{ft}$ thick or greater) is approximately 775 billion stort tons (table 1). Most of these coal resources, an ertimated 633 billion short tons, are in Wyoming, where the basin is deeper and coal beds are more num erous and tend to be thicker than those in Montana. 
About one-third (32 percent) of the area of each of the 243 quadrangles was not evaluated in this CRO/CDP map program, and therefore was not included in this estimate. Areas not evaluated in the 243 quadrangles include coal lands already leased, nonFederal coal lands, and Indian lands. Between 70 and 80 other 7.5-minute quadrangles were not evaluated in the Powder River Basin, nearly 44 of which are located in the Sheridan, Buffalo, and Lake DeSmet coal fields of Wyoming.

The geologic assurance or degree of reliability of the quadrangle coal resource estimates as suggested by the categories of measured, indicated, and inferred coal is available for the 108 quadrangles in Montana. Based upon the arithmetic means of the reliability measurements, 5 percent of the coal tonnages are measured, 25 percent are indicated, and 70 percent are inferred. I believe that the mean reliability measurements for the 135 quadrangles in Wyoming would approximate these results. This information may have been compiled by the contractor, IntraSearch Inc., but it was not presented in the quadrangle reports.

\section{Reserve base coal estimates}

The contractors were instructed by the USGS to classify all identified coal more than $5 \mathrm{ft}$ thick to a depth of $3,000 \mathrm{ft}$. This does not follow the definition of the term reserve base as used by the U.S. Bureau of Mines and U.S. Geological Survey (1976) or Wood and others (1983, p. 29$)$. Only the results presented in the 13 quadrangles in Montana by USGS geologists are in accord with the formal USGS definition of reserve base-that is, all identified coals 60 in. or more thick (for subbituminous coal) that occur to a depth of 1,000 $\mathrm{ft}$. As discussed previously, all other quadrangles (230 quadrangles) includes all coal thicker than 30 in. to a depth of $3,000 \mathrm{ft}$ in the reserve base category. Table 1 shows that there is an estimated quantity of nearly 200 billion short tons of non-leased Federal stripping coal alone in the evaluated part of the Powder River Basin.

Perhaps the most important products of the program are the CDP maps. The CDP depends on measurements of coal bed thickness and depth of overburden, computation of mining recovery factors, and the quality of the coal. A CDP map shows the parts or areas (as small as 40 acres) of that quadrangle according to the high, moderate, or low development potential of three classes of coal: 1) surface-minable or strippable coal; 2) underground-minable coal; and 3) in situ gasificaton coal.

For the Powder River Basin CRO/CDP program, however, USGS personnel judged all undergroundminable coal to have low development potential, and the development potential of gasification coal was not determined for CRO/CDP quadrangles in Montana (see table 1). Strippable coal of high development potential represents the best of the coal resources in the Powder River Basin; tonnages of that class of coal are shown on the resource map (figure 1 ).

\section{REFERENCES CITED}

American Society for Testing and Materials, 1981, Gaseous fuels; coal and coke; atmosphere analysis: Philadelphia, Pennsylvania, Annual book of ASTM standards, part 26, p. 181-399.
Baker, A.A., 1929, The northward extension of the Sheridan coal field, Big Horn and Rosebud Counties, Montana: U.S. Geological Survey Bulletin 806-B, p. 15-67.

Bohor, B.F., Kent, B.H., and Haddock, D.R., 1979, Geologic map and coal sections of the Twentymile Butte quadrangle, Campbell County, Wyoming: U.S. Geological Survey Miscellaneous Field Studies Map MF-1073, scale 1:24,000.

Coal Week, 1984, Estimates of 1983 U.S. coal production : v. 10 , no. 3 , p. 3 .

Culbertson, W.C., 1975, Preliminary geologic map and coal sections of the Wyarno quadrangle, Shridan County, Wyoming: U.S. Geological Survey Miscellaneous Field Studies Map MF-723, scale $1: 24,000,2$ sheets.

Culbertson, W.C., and Klett, M.C., 1975a, Preliminary geologic map and coal sections of the Jones Draw quadrangle, Sheridan County, Wyoming: U.S. Geological Survey Miscellaneous Field $\$$ tudies Map MF-726, scale $1: 24,000,2$ sheets.

1975b, Preliminary geologic map and coal sections of the SR Springs quadrangle, Shoridan County, Wyoming: U.S. Geological Survey Miscellaneous Field Studies Map MF-727, scale $1: 24,000,2$ sheets.

1976, Geologic map and coal sections of the Browns Mountain quadrangle, Rosebud County, Montana: U.S. Geological Survey Miscellaneous Field Studies Map MF-814, scale $1: 24,070,2$ sheets.

1979a, Geologic map and coal sections of the Forks Ranch quadrangle, Big Horn County, Montana: U.S. Geological Survey Miscellaneous Field Studies Map MF-1086, scale 1:24,000.

$1979 \mathrm{~b}$, Geologic map and coal sections of the Quietus quadrangle, Big Horn and Powder River Counties, Montana: U.S. Geological Survey Miscellaneous Field Studies Map MF-1087, scale $1: 24,000$.

Culbertson, W.C., Mapel, W.J., and Klett, M.C., 1976, Geologic map and coal sections of the Stroud Creek quadrangle, Rosebud and Big Horn Counties, Montana: U.S. Geological Survey Miscellaneous Field Studies Map MF-822, scale $1: 24,000,2$ sheets.

Doelger, N.E., and Fahy, J.W., 1980, Preliminary geologic map and coal resources of the Folmes Ranch quadrangle, Big Horn County, Montana: U.S. Geologic Survey Open-File Report 80-212, 1 map, scale $1: 24,000,18$ coal sections, 2 tables.

Galyardt, G.L., 1980a, Preliminary geologic map and coal deposits of the Appel Butte quadrangle, Campbell County, Wyoming: U.S. Geological Survey Open-File Report 80-053, 1 map, scale $1: 24,000$.

$1980 \mathrm{~b}$, Geologic map and coal deposits of the Four Bar J Ranch quadrangle, Campbell County, Wyoming: U.S. Geological Survey Opєn-File Report 80-648, 1 map, scale 1:24,000.

Galyardt, G.L., and Murray, F.N., 1981, Geologic map and coal sections of the Pearl School quadrangle and the easternmost part of the Bar V Ranch quadrangle, Big Horn County, Montana: U.S. Geological Survey Open-File Report 81-870, 1 map, scale $1: 24,000$, well logs, and tables.

Glass, G.B., 1978, Wyoming Coal Fields, 1978: Geological Survey of Wyoming, Public Information Circular No. 9, 91 p. 
1980, Coal Resources of the Powder River Basin, in Glass, G.B., ed., Guidebook to the coal geology of the Powder River Coal Basin, Wyoming: Wyoming Geological Survey Public Information Circular 14, p. 97-131.

Grazis, S.L., 1977a, Geologic map and coal resources of the Pleasantdale quadrangle, Campbell County, Wyoming: U.S. Geological Survey Coal Investigations Map C-76, scale $1: 24,000,3$ sheets. $1977 \mathrm{~b}$, Geologic map and coal resources of the Scaper Reservoir quadrangle, Campbell County, Wyoming: U.S. Geological Survey Coal Investigations Map C-77, scale $1: 24,000,3$ sheets. $1977 \mathrm{c}$, Geologic map and coal resources of the Gap SW quadrangle, Campbell County, Wyoming: U.S. Geological Survey Coal Investigations Map C-78, scale $1: 24,000,3$ sheets. $1977 \mathrm{~d}$, Geologic map and coal resources of the Saddle Horse Butte quadrangle, Campbell County, Wyoming: U.S. Geological Survey Coal Investigations Map $\mathrm{C}-79$, scale $1: 24,000,3$ sheets.

Haddock, D.R., Kent, B.H., and Bohor, B.F., 1977, Geologic map and coal sections of the Croton quadrangle, Campbell County, Wyoming: U.S. Geological Survey Miscellaneous Field Studies Map MF-826, scale 1:24,000, 1 sheet.

Hatch, J.R., and Swanson, V.E., 1977, Trace elements in Rocky Mountain coals, in Proceedings of the 1976 symposium, Geology of Rocky Mountain Coal, 1977: Colorado Geological Survey Resource Series 1, p. 143-163.

Keefer, W.R., 1974, Regional topography, physiography, and geology of the northern Great Plains: U.S. Geological Survey Open-File Report 74-50, plate A-3.

Keefer, W.R., and Schmidt, P.W., 1973, Energy resources map of the Powder River Basin, Wyoming and Montana: U.S. Geological Survey Miscellaneous Geologic Investigations Map I-847A, scale 1:500,000.

Kent, B.H., and Berlage, L.J., 1980, Geologic map of the Recluse $1^{\circ} \times 1 / 2^{\circ}$ quadrangle, Campbell and Crook Counties, Wyoming: U.S. Geological Survey Coal Investigations Map C-81-D, scale $1: 100,000$.

1981, Geologic map and coal sections of the Reservoir Creek quadrangle, Campbell County, Wyoming: U.S. Geological Survey Miscellaneous Field Studies Map MF-1336, scale 1:24,000.

Kent, B.H., Haddock, D.R., and Bohor, B.F., 1977, Geologic map and coal sections of the Truman Draw quadrangle, Campbell County, Wyoming: U.S. Geological Survey Miscellaneous Field Studies Map MF-917, scale 1:24,000.

Law, B.E., 1978, Geologic map and coal deposits of the Gillette West quadrangle, Campbell County, Wyoming: U.S. Geological Survey Miscellaneous Field Studies Map MF-974, scale 1:24,000.

Law, B.E., Barnum, B.E., and Wollenzien, T.P., 1979, Coal bed correlations in the Tongue River Member of the Fort Union Formation, Monarch, Wyoming, and Decker, Montana, areas: U.S. Geological Survey Miscellaneous Investigations Map $[-1128,1$ sheet.

Mapel, W.J., 1959, Geology and coal resources of the Buffalo-Lake DeSmet area, Johnson and Sheridan Counties, Wyoming: U.S. Geological Survey Bulletin 1078, 148 p.

1976a, Geologic map and coal sections of the Bar
$\mathrm{N}$ Draw quadrangle, Wyoming and Montana: U.S. Geological Survey Miscellaneous Field Studies Map MF-763, scale $1: 24,000,2$ sheets.

$1976 \mathrm{~b}$, Geologic map and coal sections of the Birney quadrangle, Rosebud County, Montana: U.S. Geological Survey Miscellaneous Field Studies Map MF-813, scale 1:24,000.

1978, Geologic map and coal sections of the Pine Butte School quadrangle, Big Horn County, Montana: U.S. Geological Survey Miscellaneous Field Studies Map MF-1014, scale 1:24.000, 2 sheets.

Mapel, W.J., and Dean, B.W., 1976a, Geologic map and coal sections of the Verona quadrangle, $\mathrm{S}$ 'eridan County, Wyoming: U.S. Geological Survey Miscellaneous Field Studies Map MF-762, scale $1: 24,000,2$ sheets.

$1976 \mathrm{~b}$, Preliminary geologic map and coal sections of the Ulm quadrangle, Sheridan County, Wyoming: U.S. Geological Survey Miscellaneous Field Studies Map MF-731, scale $1: 24,000,2$ sheets.

Mapel, W.J., and Malahy, M.D., 1976, Geologic map and coal sections of the Buffalo Run Creek quadrangle, Sheridan County, Wyoming: U.S. Geological Survey Miscellaneous Field Studies Map MF -792, scale $1: 24,000,1$ sheet.

Mapel, W.J., Martin, B.K., and Butler, B.A., 1978, Coal resource occurrence and coal development potential map of the Stroud Creek quacrangle, Rosebud and Big Horn Counties, Montane: U.S. Geological Survey Open-File Report 78-n38, 33 p., 54 pls., scale $1: 24,000$.

Matson, R.E., and Blumer, J.W., 1974, Quality and reserves of strippable coal, selected deposits, southeastern Montana: Montana Bureau of Mines and Geology Bulletin 91, $135 \mathrm{p}$.

McGregor, A.A., 1972, The Powder River Besin, in Geologic atlas of the Rocky Mountain region: Denver, Rocky Mountain Association of Geologists, $331 \mathrm{p}$.

McKay, E.J., 1976a, Preliminary geologic map and coal sections of the Willow Crossing quacrangle, Rosebud and Powder River Counties, Montana: U.S. Geological Survey Miscellaneous Field Studies Map MF-802, scale $1: 24,000,1$ sheet. $1976 \mathrm{~b}$, Preliminary geologic map and coal sections of the King Mountain quadrangle, Rosebud and Powder River Counties, Montana: U.S. Geological Survey Miscellaneous Field Studies Map MF-817, scale 1:24,000, 2 sheets. $1976 \mathrm{c}$, Preliminary geologic map and coal sections of the Fort Howes quadrangle, Rosebud and Powder River Counties, Montana: U.S. Geological Survey Miscellaneous Field Studies Map MF-807, scale $1: 24,000,1$ sheet.

McLellan, Marguerite, 1981a, Geologic map and coal resources of the Leslie Creek quadrangle, Powder River County, Montana: U.S. Geological Survey Miscellaneous Field Studies Map MF-1296, scale $1: 24,000$.

$1981 \mathrm{~b}$, Geologic map and coal resources of the Box Elder Creek quadrangle, Powder River County, Montana: U.S. Geological Survey Miscellaneous Field Studies Map MF-1297, scale $1: 24,000$.

Olive, W.W., 1957, The Spotted Horse coal field, Sheridan and Campbell Counties, Wyoming: U.S. Geological Survey Bulletin 1050, 83 p. 
Sarnecki, J.C., 1977, Geologic map and coal sections of the Lacey Gulch quadrangle, Big Horn and Rosebud Counties, Montana: U.S. Geological Survey Miscellaneous Field Studies Map MF-832, scale $1: 24,000,2$ sheets.

Shifflett, C.M., 1982, Map showing utility and industrial power sources in the conterminous United States: U.S. geological Survey Miscellaneous Field Studies Map MF-1392, scale $1: 2,500,000,2$ sheets, and accompanying states list (pamphlet), 22 p.

Trent, V.A., 1985, Summary of results of the Coal Resource Occurrence and Coal Development Potential mapping program in part of the Powder River Basin, Montana and Wyoming: U.S. Geological Survey Open-File Report 85-621, 49 p., 1 pl., 2 figs., 14 tables, scale 1:1,000,000.

Trumbull, J.V.A., 1960, Coal fields of the United States, Sheet 1: Washington, D.C., U.S. Geological Survey coal maps, scale 1:5,000,000.

U.S. Bureau of Land Management, 1974-77, SurfaceMinerals Management Quadrangle: U.S. Bureau of Land Management, Surface-Minerals Management Quadrangle nos. 1-110, scale $1: 126,720$.

1974, Draft Environmental Impact StatementEastern Powder River Basin of Wyoming: Cheyenne, WY, 5 vols.

1981, Powder River, Final Environmental Impact Statement, Coal: Cheyenne, WY, 88 p., appendices $\mathrm{A}-\mathrm{H}$.

U.S. Bureau of Mines, 1975-78, Minerals Yearbook, vol. I 1973-1976 : Washington, D.C., U.S. Goverment Printing Office.

U.S. Bureau of Mines and U.S. Geological Survey, 1976, Coal resource classification system of the U.S. Bureau of Mines and the U.S. Geological Survey: U.S. Geological Survey Bulletin 1450-B, 7 p.

U.S. Department of Energy, Energy Information Administration, 1979, Bituminous coal and lignite production and mine operations, 1977: U.S. Department of Energy, Energy Information Administration, Energy Data Report DOE/EIA 0118 (77), 78 p., 21 figs., 39 tables. 1980 , Bituminous coal and lignite production and mine operations, 1978: U.S. Department of Energy, Energy Information Administration,
Energy Data Reports, DOE/EIA 0118 (78), 90 p., 20 figs., 39 tables.

1981, Coal production, 1979: U.S. Department of Energy, Energy Information Administ-ation, Energy Data Report DOE/EIA 0118 (79), $9 \varepsilon$ p., 17 figs., 63 tables.

1982a, Coal production-1980: U.S. Department of Energy, Energy Information Administration, Energy Data Report DOE/EIA-0118 (80), 9§ p., 14 figs., 63 tables.

1982b, Coal production-1981: U.S. Department of Energy, Energy Information Administration, Report No. DOE/EIA-0118(82), 118 p., $1 \hat{\text { figs., }}$ 61 tables, appendices.

1983, Coal production--1982: U.S. Department of Energy, Energy Information Administration, Report No. DOE/EIA-0118 (82), 118 p., 13 figs., 61 tables, appendices.

1984, Coal Production--1983: U.S. Department of Energy, Energy Information Administation, Report No. DOE/EIA-0118(83), 121 p., 15 figs., 61 tables, appendices

1985, Coal Production--1984: U.S. Department of Energy, Energy Information Administration, Report No. DOE/EIA-0118(84), 144 p., 1f figs., 61 tables, appendices.

1986, Monthly Energy Review-November 1985: U.S. Department of Energy, Energy Information Administration, Report No. DOE/EIA0035(85/11), $125 \mathrm{p}$.

U.S. Geological Survey, 1973, Land and coal ownership in the Gillette area, Wyoming: U.S. Geological Survey Miscellaneous Investigations Map I-848-B, scale $1: 125,000,1$ sheet.

Warren, W.C., 1959, Reconnaissance geology of the Birney-Broadus coal field, Rosebud and Powder River Counties, Montana: U.S. Geological Survey Bulletin 1072-J, p. 561-585.

Wayland, R.G., 1981, New maps of Federal coal: Geological Society of America Bulletin, v. 92, p. 542-550, 14 figs., 3 tables.

Wood, G.H., Jr., Kehn, T.M., Carter, M.D., and Culbertson, W.C., 1983, Coal resource classification system of the U.S. Geological Survey: U.S. Geological Survey Circular 891, 65 p., 31 figs., 7 tables. 


\section{APPENDIX}

The following is a list by state of complete references for all of the 7.5-minute quadrangles shown on the accompanying sheet and listed in table 4 . The scale for all the reports is $1: 24,000$.

\section{MONTANA}

1. Colorado School of Mines Research Institute, 1979, Coal resource occurrence and coal development potential maps of the Miller Creek NW quadrangle, Rosebud and Custer Counties, Montana: U.S. Geological Survey Open-File Report 78-637, 17 p., 7 pls., 1 table.

2. Colorado School of Mines Research Institute, 1979, Coal resource occurrence and coal development potential maps of the Moon Creek School quadrangle, Custer County, Montana: U.S. Geological Survey Open-File Report 78-636, 14 p., 7 pls., 1 table.

3. Colorado School of Mines Research Institute, 1978, Coal resource occurrence and coal development potential maps of the Griffin Coulee SW quadrangle, Rosebud and Treasure Counties, Montana: U.S. Geological Survey Open-File Report 78-647, 17 p., 7 pls., 1 table.

4. Colorado School of Mines Research Institute, 1979, Coal resource occurrence and coal development potential maps of the McKerlich Creek quadrangle, Rosebud County, Montana: U.S. Geological Survey Open-File Report 78-641, 15 p., 10 pls., 1 table.

5. Colorado School of Mines Research Institute, 1979, Coal resource occurrence and coal development potential maps of the Crain Place quadrangle, Rosebud County, Montana: U.S. Geological Survey Open-File Report 78-644, 18 p., 11 pls., 1 table.

6. Colorado School of Mines Research Institute, 1979, Coal resource occurrence and coal development potential maps of the Miller Creek SW quadrangle, Custer and Rosebud Counties, Montana: U.S. Geological Survey Open-File Report 78-646, 18 p., 12 pls., 2 tables.

7. Colorado School of Mines Research Institute, 1979, Coal resource occurrence and coal development potential maps of the Miller Creek quadrangle, Custer County, Montana: U.S. Geological Survey Open-File Report 78-635, 16 p., 7 pls., 2 tables.

8. Colorado School of Mines Research Institute, 1978, Coal resource occurrence and coal development potential maps of the Jack Creek quadrangle, Custer County, Montana: U.S. Geological Survey Open-File Report 78-639, 16 p., 8 pls., 1 table.

9. Colorado School of Mines Research Institute, 1979, Coal resource occurrence and coal development potential maps of the Beebe SW quadrangle, Custer County, Montana: U.S. Geological Survey Open-File Report 78-634, 8 p., 3 pls.
10. Colorado School of Mines Research Institute, 1979, Coal resource occurrence and coal development potential maps of the Iron Spring quadrangle, Big Horn and Trsasure Counties, Montana: U.S. Geological Survey Open-File Report 78-631, 8 p., 3 pls.

11. Colorado School of Mines Research Institute, 1979, Coal resource occurrence and coal development potential maps of the Minnehaha Creek South quadrangle, Treasure and Big Horn Counties, Montana: U.S. Geological Survey Open-File Report 78-833, 21 p., 16 pls., 1 table.

12. Colorado School of Mines Research Institute, 1979, Coal resource occurrence and coal development potential maps of the McClure Creek quadrangle, Rosebud and Tr sasure Counties, Montana: U.S. Geological Survey Open-File Report 78-834, 22 p., 15 pls., 2 tables.

13. Colorado School of Mines Research Institute, 1979, Coal resource occurrence and coal development potential maps of the Trail Creek School quadrangle, Rosebud County, Montana: U.S. Geological Survey Open-File Report 78-835, 20 p., 13 pls., 1 table.

14. Colorado School of Mines Research Institute, 1979, Coal resource occurrence and coal development potential maps of the Colstrip West quadrangle, Rosebud County, Montana: U.S. Geological Survey Open-File Report 78-648, 20 p., 13 pls., 1 table.

15. Colorado School of Mines Research Institute, 1978, Coal resource occurrence and coal development potential maps of the Colstrip East quadrangle, Rosebud County, Montana: U.S. Geological Survey Open-File Report 78-836, 18 p., 13 pls., 1 table.

16. Colorado School of Mines Research Institute, 1979, Coal resource occurrence and coal development potential maps of the Hammond Draw NW quadrangle, Rosebud County, Montana: U.S. Geological Survey Open-File Report 78-645, 18 p., 10 pls., 1 table.

17. Colorado School of Mines Research Institute, 1979, Coal resource occurrence ant coal development potential maps of the John Hen Creek quadrangle, Rosebud County, Montana: U.S. Geological Survey Open-File Report 78-643, 18 p., 10 pls., 1 table.

18. Colorado School of Mines Research Institute, 1979, Coal resource occurrence and coal development potential maps of the Brandenberg NW quadrangle, Custer and Rosebud Counties, Montana: U.S. Geological Survey Open-File Report 78-642, 17 p., 7 pls., 1 table. 
19. Colorado School of Mines Research Institute, 1979, Coal resource occurrence and coal development potential maps of the $\mathrm{H} \mathrm{S}$ School quadrangle, Custer County, Montana: U.S. Geological Survey Open-File Report 78-638, 16 p., 7 pls., 1 table.

20. Colorado School of Mines Research Institute, 1979, Coal resource occurrence and coal development potential maps of the Fourmile Creek quadrangle, Custer County, Montana: U.S. Geological Survey Open-File Report 78-640, 16 p., 8 pls., 1 table.

21. Colorado School of Mines Research Institute, 1979, Coal resource occurrence and coal development potential maps of the CareyMalone School quadrangle, Custer County, Montana: U.S. Geological Survey Open-File Report 78-837, 20 p., 11 pls., 2 tables.

22. Colorado School of Mines Research Institute, 1979, Coal resource occurrence and coal development potential maps of the Kirkpatrick Hill quadrangle, Custer County, Montana: U.S. Geological Survey Open-File Report 78-838, 20 p., 10 pls., 2 tables.

23. Colorado School of Mines Research Institute, 1979, Coal resource occurrence and coal development potential maps of the Padlock Ranch quadrangle, Big Horn County, Montana: U.S. Geological Survey Open-File Report 78-633, 9 p., 3 pls.

24. Colorado School of Mines Research Institute, 1979, Coal resource occurrence and coal development potential maps of the Iron Spring SW quadrangle, Big Horn County, Montana: U.S. Geological Survey Open-File Report 78-632, 9 p., 3 pls.

25. Colorado School of Mines Research Institute, 1979, Coal resource occurrence and coal development potential maps of the Wolf School quadrangle, Big Horn and Treasure Counties, Montana: U.S. Geological Survey Open-File Report 79-20, 25 p., 17 pls., 2 tables.

26. Colorado School of Mines Research Institute, 1979, Coal resource occurrence and coal development potential maps of the Sarpy School quadrangle, Big Horn, Rosebud, and Treasure Counties, Montana: U.S. Geological Survey Open-File Report 79-18, 22 p., 13 over-size sheets.

27. Colorado School of Mines Research Institute, 1979, Coal resource occurrence and coal development potential maps of the Rough Draw quadrangle, Rosebud County, Montana: U.S. Geological Survey Open-File Report 79-17, 28 p., 22 over-size sheets.

28. Colorado School of Mines Research Institute, 1979, Coal resource occurrence and coal development potential maps of the Colstrip SW quadrangle, Rosebud County, Montana: U.S. Geological Survey Open-File Report 79-7, 24 p., 17 over-size sheets.

29. Colorado School of Mines Research Institute, 1979, Coal resource occurrence and coal development potential maps of the Colstrip SE quadrangle, Rosebud County, Montana: U.S. Geological Survey Open-File Peport 79-6, 23 p., 17 pls., 1 table.

30. Colorado School of Mines Research Ins ${ }^{+}$itute, 1979, Coal resource occurrence and coal development potential maps of the Hammond Draw SW quadrangle, Rosebud County, Montana: U.S. Geological survey Open-File Report 79-12, 22 p., 16 pls, 1 table.

31. Colorado School of Mines Research Institute, 1979, Coal resource occurrence and coal development potential maps of the Hammond Draw quadrangle, Rosebud County, Montana: U.S. Geological s.urvey Open-File Report 79-11, 23 p., 16 over-size sheets.

32. Colorado School of Mines Research Institute, 1979, Coal resource occurrence and coal development potential maps of the Brandenberg quadrangle, Rosebud and Powder River Counties, Montana: U.S. Geological Survey Open-File Report 79-4, 20 p., 13 pls., 2 tables.

33. Colorado School of Mines Research Institute, 1979, Coal resource occurrence and coal development potential maps of the Hayes Point quadrangle, Custer and Powder River Counties, Montana: U.S. Geological s'urvey Open-File Report 79-13, 22 p., 16 over-size sheets.

34. Colorado School of Mines Research Institute, 1979, Coal resource occurrence and coal development potential maps of the North Stacey School quadrangle, Custer and Powder River Counties, Montana: U.S. Geological Survey Open-File Report 79-16, 27 p., 22 pls., 2 tables.

35. Colorado School of Mines Research Institute, 1979, Coal resource occurrence and coal development potential maps of the Foster Creek School quadrangle, Custer and Powder River Counties, Montana: U.S. Geological Survey Open-File Report 79-9, 23 p., 14 pls., 2 tables.

36. Colorado School of Mines Research Institute, 1979, Coal resource occurrence and coal development potential maps of the Volborg quadrangle, Custer and Powder River Counties, Montana: U.S. Geological s'urvey Open-File Report 79-19, 23 p., 13 pls., 2 tables.

37. Colorado School of Mines Research Institute, 1979, Coal resource occurrence and coal development potential maps of the Divide School quadrangle, Custer and Powder River Counties, Montana: U.S. Geolngical Survey Open-File Report 79-8, 19 p., 10 pls., 1 table.

38. Colorado School of Mines Research Institute, 1979, Coal resource occurrence and coal development potential maps of the Jeans Fork NE quadrangle, Big Horn County, 
Montana: U.S. Geological Survey Open-File Report 79-14, 19 p., 6 pls., 1 table.

39. Colorado School of Mines Research Institute, 1980, Coal resource occurrence and coal development potential maps of the Chalky Point quadrangle, Big Horn and Rosebud Counties, Montana: U.S. Geological Survey Open-File Report 79-5, 20 p., 9 over-size sheets.

40. Colorado School of Mines Research Institute, 1980, Coal resource occurrence and coal development potential maps of the Black Spring quadrangle, Rosebud and Big Horn Counties, Montana: U.S. Geological Survey Open-File Report 79-3, 21 p., 16 over-size sheets.

41. Colorado School of Mines Research Institute, 1980, Coal resource occurrence and coal development potential maps of the Jimtown quadrangle, Rosebud and Big Horn Counties, Montana: U.S. Geological Survey Open-File Report 79-15, 21 p., 10 over-size sheets.

42. Colorado School of Mines Research Institute, 1979, Coal resource occurrence and coal development potential maps of the Badger Peak quadrangle, Rosebud County, Montana: U.S. Geological Survey Open-File Report 79-2, 25 p., 16 pls., 2 tables.

43. Colorado School of Mines Research Institute, 1979, Coal resource occurrence and coal development potential maps of the Garfield Peak quadrangle, Rosebud County, Montana: U.S. Geological Survey Open-File Report 79-10, 23 p., 13 pls., 2 tables.

44. Colorado School of Mines Research Institute, 1979, Coal resource occurrence and coal development potential maps of the Ashland NE quadrangle, Rosebud County, Montana: U.S. Geological Survey Open-File Report 79-1, 22 p., 19 pls., 1 table.

45. Colorado School of Mines Research Institute, 1979, Coal resource occurrence and coal development potential maps of the Cook Creek Reservoir quadrangle, Powder River and Rosebud Counties, Montana: U.S. Geological Survey Open-File Report 79-84, 27 p., 35 pls., 2 tables.

46. Colorado School of Mines Research Institute, 1980, Coal resource occurrence and coal development potential maps of the Beaver Creek School quadrangle, Powder River County, Montana: U.S. Geological Survey Open-File Report 79-79, 31 p., 32 over-size sheets.

47. Colorado School of Mines Research Institute, 1979, Coal resource occurrence and coal development potential maps of the Stacey quadrangle, Powder River County, Montana: U.S. Geological Survey Open-File Report 79-99, 26 p., 25 pls., 2 tables.

48. Colorado School of Mines Research Institute, 1979, Coal resource occurrence and coal development potential maps of the Elk Ridge quadrangle, Powder River County,
Montana: U.S. Geological Survey Open-File Report 79-85, 26 p., 19 oversize sheets.

49. Colorado School of Mines Research Institute, 1980, Coal resource occurrence and coal development potential maps of th? Box Elder Creek quadrangle, Powder River County, Montana: U.S. Geological Survey Open-File Report 79-81, 26 p., 16 over-size sheets.

50. Colorado School of Mines Research Institute, 1980, Coal resource occurrence and coal development potential maps of the Coalwood quadrangle, Powder River County, Montana: U.S. Geological Survey Open-File Report 79-82, 22 p., 17 over-size sheets.

51. Colorado School of Mines Research Institute, 1979, Coal resource occurrence and coal development potential maps of the Ashland quadrangle, Rosebud County, Montana: U.S. Geological Survey Open-File Report 79-78, 23 p., 16 pls., 2 tables.

52. Colorado School of Mines Research Institute, 1980, Coal resource occurrence and coal development potential maps of the Willow Crossing quadrangle, Powder River and Rosebud Counties, Montana: U.S. Geological Survey Open-File Report 79-101, 26 p., 14 over-size sheets.

53. Colorado School of Mines Research Institute, 1980, Coal resource occurrence and coal development potential maps of the Coleman Draw quadrangle, Powder River County, Montana: U.S. Geological Survey Open-File Report 79-83, 28 p., 31 over-size sheets.

54. Colorado School of Mines Research Institute, 1980, Coal resource occurrence and coal development potential maps of the Home Creek Butte quadrangle, Powder River County, Montana: U.S. Geological Survey Open-File Report 79-91, 34 p., 41 over-size sheets.

55. Colorado School of Mines Research Institute, 1980, Coal resource occurrence and coal development potential maps of the Samuelson Ranch quadrangle, Powder River County, Montana: U.S. Geological Survey Open-File Report 79-97, 28 p., 25 over-size sheets.

56. Colorado School of Mines Research Institute, 1980, Coal resource occurrence and coal development potential maps of the Leslie Creek quadrangle, Powder River County, Montana: U.S. Geological Survey Open-File Report 79-93, 25 p., 16 over-size sheets.

57. Colorado School of Mines Research Institute, 1979, Coal resource occurrence and coal development potential maps of the Olive quadrangle, Powder River County, Montana: U.S. Geological Survey Open-File Report 79-95, 18 p., 11 over-size sheets.

58. Colorado School of Mines Research Institute, 1980, Coal resource occurrence and coal development potential maps of the Cook 
Creek Butte quadrangle, Rosebud and Big Horn Counties, Montana: U.S. Geological Survey Open-File Report 79-646, 22 p., 13 over-size sheets.

59. Mapel, W.J., and Martin, B. K., 1978, Coal resource occurrence and coal development potential maps of the southern part of the Clubfoot Creek quadrangle, Rosebud County, Montana: U.S. Geological Survey Open-File Report 78-41, 23 p., 34 pls., 3 tables.

60. Colorado School of Mines Research Institute, 1980 , Coal resource occurrence and coal development potential maps of the Birney Day School quadrangle, Rosebud County, Montana: U.S. Geological Survey Open-File Report 79-80, 33 p., 35 over-size sheets.

61. Colorado School of Mines Research Institute, 1980 , Coal resource occurrence and coal development potential maps of the Green Creek quadrangle, Rosebud County, Montana: U.S. Geological Survey Open-File Report 79-89, 36 p., 42 over-size sheets.

62. Colorado School of Mines Research Institute, 1980, Coal resource occurrence and coal development potential maps of the King Mountain quadrangle, Powder River and Rosebud Counties, Montana: U.S. Geological Survey Open-File Report 79-92, 37 p., 43 over-size sheets.

63. Colorado School of Mines Research Institute, 1980, Coal resource occurrence and coal development potential maps of the Yager Butte quadrangle, Powder River County, Montana: U.S. Geological Survey Open-File Report 79-102, 36 p., 44 over-size sheets.

64. Colorado School of Mines Research Institute, 1980, Coal resource occurrence and coal development potential maps of the Threemile Buttes quadrangle, Powder River County, Montana: U.S. Geological Survey Open-File Report 79-100, 38 p., 53 oversize sheets.

65. Colorado School of Mines Research Institute, 1980, Coal resource occurrence and coal development potential maps of the Sonnette quadrangle, Powder River County, Montana: U.S. Geological Survey Open-File Report 79-98, 33 p., 38 over-size sheets.

66. Colorado School of Mines Research Institute, 1980, Coal resource occurrence and coal development potential maps of the Epsie quadrangle, Powder River County, Montana: U.S. Geological Survey Open-File Report 79-86., 28 p., 25 over-size sheets.

67. Colorado School of Mines Research Institute, 1979, Coal resource occurrence and coal development potential maps of the Epsie NE quadrangle, Power River County, Montana: U.S. Geological Survey Open-File Report 79-87, 21 p., 11 over-size sheets.

68. Colorado School of Mines Research Institute, 1980, Coal resource occurrence and coal development potential maps of the Spring
Creek Ranch quadrangle, Big Horn County, Montana: U.S. Geological Survey Opon-File Report 79-777, 21 p., 13 over-size sheets.

69. Colorado School of Mines Research Institute, 1980, Coal resource occurrence and coal development potential maps of the Kirby quadrangle, Big Horn County, Montana: U.S. Geological Survey Open-File Report 79-650, 28 p., 28 over-size sheets.

70. Colorado School of Mines Research Institute, 1980, Coal resource occurrence and coal development potential maps of the Taintor Desert quadrangle, Big Horn and Rosebud Counties, Montana: U.S. Geological Survey Open-File Report 79-779, 28 p., 27 oversize sheet.

71. Colorado School of Mines Research Institute, 1980, Coal resource occurrence and coal development potential maps of the Birney SW quadrangle, Rosebud and Big Horn Counties, Montana: U.S. Geological Survey Open-File Report 79-645, 27 p, 22 over-size sheets.

72. Mapel, W.J., and Martin, B.K., 1979, Coal resource occurrence and coal development potential maps of the Birney quadiangle, Rosebud County, Montana: U.S. Gec'ogical Survey Open-File Report 78-30, 24 p., 44 pls., 2 tables.

73. Mapel, W.J., and Martin, B.K. 1978, Coal resource occurrence and coal development potential maps of the Browns Mountain quadrangle, Rosebud County, Montana: U.S. Geological Survey Open-File Report 78-39, 36 p., 69 pls., 6 tables.

74. Mapel, W.J., Martin, B.K, and Butler, B.A., 1979, Coal resource occurrence ard coal development potential maps of the Poker Jim Butte quadrangle, Rosebud and Powder River Counties, Montana: U.S. Geclogical Survey Open-File Report 78-651, 33 p., 64 pls., 3 tables.

75. McKay, E.J. and Robinson, L.N., 1979, Coal resource occurrence and coal development potential maps of the Fort Howes quadrangle, Rosebud and Powder River Counties, Montana: U.S. Geological Survey Open-File Report 79-104, 26 p., 53 pls, 2 tables.

76. Colorado School of Mines Research In-titute, 1980, Coal resource occurrence and coal development potential maps of the Goodspeed Butte quadrangle, Powder River County, Montana: U.S. Geological Survey Open-File Report 79-88, 34 p., 37 over-size sheets.

77. Colorado School of Mines Research In $>$ titute, 1980, Coal resource occurrence and coal development potential maps of the Phillips Butte quadrangle, Powder River County, Montana: U.S. Geological Survey Open-File Report 79-96, 36 p., 41 over-size she ots.

78. Colorado School of Mines Research In titute, 1980, Coal resource occurrence and coal 
development potential maps of the Hodsdon Flats quadrangle, Powder River County, Montana: U.S. Geological Survey Open-File Report 79-90, 36 p., 40 over-size sheets.

79. Colorado School of Mines Research Institute, 1980, Coal resource occurrence and coal development potential maps of the Yarger Butte quadrangle, Powder River County, Montana: U.S. Geological Survey Open-File Report 79-103, 25 p., 24 over-size sheets.

80. Colorado School of Mines Research Institute, 1980, Coal resource occurrence and coal development potential maps of the Lonesome Peak quadrangle, Powder River County, Montana: U.S. Geological Survey Open-File Report 79-94, 24 p., 21 over-size sheets.

81. Colorado School of Mines Research Institute, 1980 , Coal resource occurrence and coal development potential maps of the Bar $V$ Ranch NE quadrangle, Big Horn County, Montana: U.S. Geological Survey Open-File Report 79-644, 29 p., 26 over-size sheets.

82. Colorado School of Mines Research Institute, 1980, Coal resource occurrence and coal development potential maps of the Half Moon Hill quadrangle, Big Horn County, Montana: U.S. Geological Survey Open-File Report 79-648, 31 p., 37 over-size sheets.

83. Colorado School of Mines Research Institute, 1980, Coal resource occurrence and coal development potential maps of the Tongue River Dam quadrangle, Big Horn and Rosebud Counties, Montana: U.S. Geological Survey Open-File Report 79-780, 30 p., 30 over-size sheets.

84. Colorado School of Mines Research Institute, 1980, Coal resource occurrence and coal development potential maps of the Spring Gulch quadrangle, Rosebud and Big Horn Counties, Montana: U.S. Geological Survey Open-File Report 79-778, 34 p., 32 oversize sheets.

85. Mapel, W.J., and Martin, B.K., and Butler, B.A., 1978, Coal resource occurrence and coal development potential maps of the Lacey Gulch quadrangle, Rosebud County, Montana: U.S. Geological Survey Open-File Report 78-37, 31 p., 49 pls., 2 tables.

86. Mapel, W.J., Martin, B.K., and Butler, B.A., 1978, Coal resource occurrence and coal development potential maps of the Stroud Creek quadrangle, Rosebud and Big Horn Counties, Montana: U.S. Geological Survey Open-File Report 78-38, 34 p., 54 pls., 4 tables.

87. Mapel, W.J., Martin, B.K., and Butler, B.A., 1979 , Coal resource occurrence and coal development potential maps of the Hamilton Draw quadrangle, Rosebud, Big Horn, and Powder River Counties, Montana: U.S. Geological Survey Open-File Report 78-40, 32 p., 54 pls., 2 tables.

88. McKay, E.J., and Robinson, L.N., 1979, Coal resource occurrence and coal development potential maps of the Otter quadrangle, Powder River County, Montana: U.S. Geological Survey Open-File Report 79-105, 22 p., 59 pls., 2 tables.

89. Colorado School of Mines Research Institute, 1980, Coal resource occurrence and coal development potential maps of the Reanus Cone quadrangle, Powder River County, Montana: U.S. Geological Survey $C$,en-File Report 79-788, 38 p., 38 over-size sheets.

90. Colorado School of Mines Research Institute, 1980, Coal resource occurrence and coal development potential maps of the Sayle quadrangle, Powder River County, Montana: U.S. Geological Survey C sen-File Report 79-789, 35 p., 41 over-size sheets.

91. Colorado School of Mines Research Institute, 1980, Coal resource occurrence and coal development potential maps of the Bloom Creek quadrangle, Powder River County, Montana: U.S. Geological Survey C ren-File Report 79-784, 33 p., 36 over-size sheets.

92. Colorado School of Mines Research Institute, 1980, Coal resource occurrence and coal development potential maps of the Huckins School quadrangle, Powder River County, Montana: U.S. Geological Survey $C$ Jen-File Report 79-786, 33 p., 41 over-size sheets.

93. Colorado School of Mines Research Institute, 1980, Coal resource occurrence and coal development potential maps of the Baldy Peak quadrangle, Powder River County, Montana: U.S. Geological Survey C pen-File Report 79-781, 28 p., 30 over-size sheets.

94. Colorado School of Mines Research Institute, 1980, Coal resource occurrence and coal development potential maps of the Bear Skull Mountain quadrangle, Powdor River County, Montana: U.S. Geological Survey Open-File Report 79-783, 27 p., 23 oversize sheets.

95. Colorado School of Mines Research Institute, 1980, Coal resource occurrence and coal development potential maps of tre Bar $\mathrm{V}$ Ranch quadrangle, Big Horn County, Montana: U.S. Geological Survey C pen-File Report 79-643, 27 p., 25 over-size sheets.

96. Colorado School of Mines Research Institute, 1980 , Coal resource occurrence and coal development potential maps of the Pearl School quadrangle, Big Horn County, Montana: U.S. Geological Survey C jen-File Report 79-776, 34 p., 43 over-size sheets.

97. Colorado School of Mines Research Institute, 1980, Coal resource occurrence and coal development potential maps of the Decker quadrangle, Big Horn County, Montana: U.S. Geological Survey Open-File. Report 79-647, 33 p., 45 over-size sheets.

98. Colorado School of Mines Research Institute, 1980, Coal resource occurrence and coal development potential maps of the Holmes Ranch quadrangle, Big Horn County, 
Montana: U.S. Geological Survey Open-File Report 79-649, 34 p., 37 over-size sheets.

99. Culbertson, W.C., Robinson, L.N. and Gaffke, T.M., 1979, Coal resource occurrence and coal development potential maps of the Pine Butte School quadrangle, Big Horn County, Montana: U.S. Geological Survey Open-File Report 78-652, 30 p., 64 pls., 2 tables.

100. Culbertson, W.C., Robinson, L.N., and Gaffke, T.M., 1979, Coal resource occurrence and coal development potential maps of the Forks Ranch quadrangle, Big Horn County, Montana: U.S. Geological Survey Open-File Report 78-653, 31 p., 59 pls, 4 tables.

101. Culbertson, W.C. and Robinson, L.N., 1979, Coal resource occurrence and coal development potential maps of the Quietus quadrangle, Big Horn and Powder River Counties, Montana: U.S. Geological Survey Open-File Report 78-654, 26 p., 44 pls., 4 tables.

102. McKay, E.J., Butler, B.A., and Robinson, L.N., 1979, Coal resource occurrence and coal development potential maps of the Bear Creek School quadrangle, Powder River County, Montana: U.S. Geological Survey Open-File Report 79-106, 20 p., 59 oversize sheets.

103. Colorado School of Mines Research Institute, 1981, Coal resource occurrence and coal development potential maps of the Sayle Hall quadrangle, Powder River County, Montana: U.S. Geological Survey Open-File Report 79-0790, 36 p., 46 over-size sheets.
104. Colorado School of Mines Research In-titute, 1981, Coal resource occurrence and coal development potential maps $c^{f}$ the Bradshaw Creek quadrangle, Powden River County, Montana: U.S. Geological Survey Open-File Report 79-785, 35 p., 39 oversize sheets.

105. Colorado School of Mines Research In-titute, 1981, Coal resource occurrence and coal development potential maps of the Moorhead quadrangle, Powder River County, Montana: U.S. Geological Survey Open-File Report 79-787, 31 p., 30 oversize sheets.

106. Colorado School of Mines Research In titute, 1981, Coal resource occurrence and coal development potential maps of the. Three Bar Ranch quadrangle, Powder River County, Montana and Campbell County, Wyoming: U.S. Geological Survey OpenFile Report 79-791, 33 p., 35 orer-size sheets.

107. Colorado School of Mines Research In titute, 1981, Coal resource occurrence and coal development potential maps of the Bay Horse quadrangle, Powder River County, Montana: U.S. Geological Survey Ofen-File Report 79-782, 28 p., 27 over-size shaets.

108. Colorado School of Mines Research In titute, 1980, Coal resource occurrence and coal development potential maps of the Vild Bill Creek quadrangle, Powder River County, Montana: U.S. Geological Survey Ofen-File Report 79-792, 23 p., 13 over-size shoets.
1. IntraSearch, Inc., 1981, Coal resource occurrence and coal development potential maps of Box Elder Draw quadrangle, Sheridan County, Wyoming, and Big Horn and Powder River Counties, Montana: U.S. Geological Survey Open-File Report 79-162, 36 p., 49 over-size sheets.

2. IntraSearch, Inc., 1981, Coal resource occurrence and coal development potential maps of the Cabin Creek NW quadrangle, Sheridan County, Wyoming, and Powder River County, Montana: U.S. Geological Survey Open-File Report 79-163, 39 p., 59 over-size sheets.

3. IntraSearch, Inc., 1980, Coal resource occurrence and coal development potential maps of the Cabin Creek NE quadrangle, Sheridan and Campbell Counties, Wyoming: U.S. Geological Survey OpenFile Report 78-64, 49 p., 44 over-size sheets.

4. IntraSearch, Inc., 1979, Coal resource occurrence and coal development potential maps of the Black Draw quadrangle, Campbell County, Wyoming and Powder River County, Montana: U.S. Geological
Survey Open-File Report 78-65, 27 p., 39 pls., 3 tables.

5. IntraSearch, Inc., 1980, Coal resource occurrence and coal development potential maps of the Dead Horse Lake quadrangle, Campbell County, Wyoming: U.S. Geological Survey Open-File Report 78-66, 33 p., 40 over-size sheets.

6. IntraSearch, Inc., 1979, Coal resource occurrence and coal development potential maps of the Corral Creek quadrangle, Campbell County, Wyoming: U.S. Geological Survey Open-File Report 78-67, 28 p., 39 pl., 3 tables.

7. IntraSearch, Inc., 1979, Coal rasource occurrence and coal development potential maps of the Homestead Draw quadrangle, Campbell County, Wyoming: U.S. Geological Survey Open-File Report 78-829, 30 p., 29 pls., 3 tables.

8. IntraSearch, Inc., 1979, Coal resource occurrence and coal development pitential maps of the Rocky Butte quadrangle, Campbell County, Wyoming: U.S. Geological Survey Open-File Report 78-830, 27 p., 24 pls, 3 tables. 
9. IntraSearch, Inc., 1981, Coal resource occurrence and coal development potential maps of the Fawn Draw quadrangle, Sheridan County, Wyoming: U.S. Geological Survey Open-File Report 79-164, 36 p., 59 over-size sheets.

10. IntraSearch, Inc., 1981, Coal resource occurrence and coal development potential maps of the Cabin Creek SE quadrangle, Sheridan and Campbell Counties, Wyoming: U.S. Geological Survey OpenFile Report $79-165,43$ p., 49 over-size sheets.

11. IntraSearch, Inc., 1979, Coal resource occurrence and coal development potential maps of the Kline Draw quadrangle, Campbell County, Wyoming: U.S. Geological Survey Open-File Report 78-831, 30 p., 34 pls., 3 tables.

12. IntraSearch, Inc., 1979, Coal resource occurrence and coal development potential maps of the Reservoir Creek quadrangle, Campbell County, Wyoming: U.S. Geological Survey Open-File Report 78-832, 28 p., 40 pls., 3 tables.

13. IntraSearch, Inc., 1979, Coal resource occurrence and coal development potential maps of the Homestead Draw Southwest quadrangle, Campbell County, Wyoming: U.S. Geological Survey Open-File Report 78-655, 32 p., 44 pls., 3 tables.

14. IntraSearch, Inc., 1979, Coal resource occurrence and coal development potential maps of the White Tail Butte quadrangle, Campbell County, Wyoming: U.S. Geological Survey Open-File Report 79-21, 30 p., 42 pls., 3 tables.

15. IntraSearch, Inc., 1979, Coal resource occurrence and coal development potential maps of the Rocky Butte Southwest quadrangle, Campbell County, Wyoming: U.S. Geological Survey Open-File Report 79-22, 29 p., 24 pls., 3 tables.

16. IntraSearch, Inc., 1981, Coal resource occurrence and coal development potential maps of the Arvada quadrangle, Sheridan County, Wyoming: U.S. Geological Survey Open-File Report 79-166, 41 p., 45 oversize sheets.

17. IntraSearch, Inc., 1981, Coal resource occurrence and coal development potential maps of the Arvada NE quadrangle, Sheridan and Campbell Counties, Wyoming: U.S. Geological Survey OpenFile Report 79-167, 41 p., 55 over-size sheets.

18. IntraSearch, Inc., 1979, Coal resource occurrence and coal development potential maps of the Larey Draw quadrangle, Campbell County, Wyoming: U.S. Geological Survey Open-File Report 79-23, 35 p., 54 pls., 3 tables.

19. IntraSearch, Inc., 1979, Coal resource occurrence and coal development potential maps of the Spotted Horse qurdrangle, Campbell County, Wyoming: U.S. Geological Survey Open-File Report 79-24, 33 p., 50 pls., 3 tables.

20. IntraSearch, Inc., 1979, Coal resource occurrence and coal development potential maps of the Recluse quadrangle, Campbell County, Wyoming: U.S. Geological Survey Open-File Report 79-25, 34 p., 46 pls., 3 tables.

21. IntraSearch, Inc., 1979, Coal resource occurrence and coal development potential maps of the Pitch Draw quedrangle, Campbell County, Wyoming: U.S. Geological Survey Open-File Report 79-26, 31 p., 41 pls., 3 tables.

22. IntraSearch, Inc., 1979, Coal resource occurrence and coal development potential maps of the Oliver Draw quedrangle, Campbell County, Wyoming: U.S. Geological Survey Open-File Report 79-27, 29 p., 19 pls., 3 tables.

23. IntraSearch, Inc., 1981, Coal resource occurrence and coal development potential maps of Jewell Draw quadrangle, Sheridan and Johnson Counties, Wyoming: U.S. Geological Survey Open-File Report 79-168, 39 p., 45 over-size sheets.

24. IntraSearch, Inc., 1981, Coal resource occurrence and coal development potential maps of the Lariat quadrangle, Sheridan, Johnson, and Campbell Counties, Wyoming: U.S. Geological Surve" OpenFile Report $79-169,33$ p., 55 cver-size sheets.

25. IntraSearch, Inc., 1979, Coal resource occurrence and coal development potential maps of the Croton quadrangle, Campbell County, Wyoming: U.S. Geological Survey Open-File Report 79-28, 36 p., 65 pls., 3 tables.

26. IntraSearch, Inc., 1980, Coal resource occurrence and coal development potential maps of the Truman Draw quedrangle, Campbell County, Wyoming: U.S. Geological Survey Open-File Report 79-29, 39 p., 75 over-size sheets.

27. IntraSearch, Inc., 1980, Coal resource occurrence and coal development potential maps of the Wildeat quadrangle, Campbell County, Wyoming: U.S. Geological Survey Open-File Report 79-30, 35 p., 76 cver-size sheets.

28. IntraSearch, Inc., 1979, Coal resource occurrence and coal development potential maps of the Calf Creek quedrangle, Campbell County, Wyoming: U.S. Geological Survey Open-File Report 79-31, 31 p., 40 pls., 3 tables.

29. IntraSearch, Inc., 1979, Coal resource occurrence and coal development potential maps of the Weston SW quadrangla. Campbell County, Wyoming: U.S. Geological Survey Open-File Report 79-32, 32 p., 15 
pls., 3 figs., 3 tables.

30. IntraSearch, Inc., 1981, Coal resource occurrence and coal development potential maps of the Mitchell Draw quadrangle, Johnson County, Wyoming: U.S. Geological Survey Open-File Report 79-170, 32 p., 40 over-size sheets.

31. IntraSearch, Inc., 1981, Coal resource occurrence and coal development potential maps of the Livingston Draw quadrangle, Johnson and Campbell Counties, Wyoming: U.S. Geological Survey Open-File Report 79-171, 39 p., 50 over-size sheets.

32. IntraSearch, Inc., 1980, Coal resource occurrence and coal development potential maps of the Echeta quadrangle, Campbell County, Wyoming: U.S. Geological Survey Open-File Report 79-33, 29 p., 40 over-size sheets.

33. IntraSearch, Inc., 1980, Coal resource occurrence and coal development potential maps of the Twentymile Butte quadrangle, Campell County, Wyoming: U.S. Geological Survey Open-File Report 79-34, 29 p., 40 over-size sheets.

34. IntraSearch, Inc., 1980, Coal resource occurrence and coal development potential maps of the Oriva NW quadrangle, Campbell County, Wyoming: U.S. Geological Survey Open-File Report 79-35, 33 p., 57 over-size sheets.

35. IntraSearch, Inc., 1980, Coal resource occurrence and coal development potential maps of the Rawhide School quadrangle, Campbell County, Wyoming: U.S. Geological Survey Open-File Report 79-36, 31 p., 40 over-size sheets.

36. IntraSearch, Inc., 1979, Coal resource occurrence and coal development potential maps of the Moyer Springs quadrangle, Campbell County, Wyoming: U.S. Geological Survey Open-File Report 79-37, 29 p., 25 pls., 3 tables.

37. IntraSearch, Inc., 1981, Coal resource occurrence and coal development potential maps of the Somerville Flats West quadrangle, Johnson County, Wyoming: U.S. Geological Survey Open-File Report $79-172,47$ p. 40 over-size sheets.

38. IntraSearch, Inc., 1981, Coal resource occurrence and coal development potential maps of the Somerville Flats. East quadrangle, Johnson and Campbell Counties, Wyoming: U.S. Geological Survey Open-File Report 79-173, 41 p., 57 oversize sheets.

39. IntraSearch, Inc., 1980, Coal resource occurrence and coal development potential maps of the Carr Draw quadrangle, Campbell County, Wyoming: U.S. Geological Survey Open-File Report 79-38, 30 p., 40 over-size sheets.

40. IntraSearch, Inc., 1980, Coal resource occurrence and coal development potential maps of the Jeffers Draw quadrangle, Campbell County, Wyoming: U.S. Geological Survey Open-File Report 79-39, 31 p., 45 over-size sheets.

41. IntraSearch, Inc., 1980, Coal resource occurrence and coal development pitential maps of the Oriva quadrangle, Campbell County, Wyoming: U.S. Geological Survey Open-File Report 79-40, 33 p., 52 over-size sheets.

42. IntraSearch, Inc., 1980, Coal resource occurrence and coal development potential maps of the Gillette West quadrangle, Campbell County, Wyoming: U.S. Geological Survey Open-File Report 79-41, 37 p., 30 over-size sheets.

43. IntraSearch, Inc., 1979, Coal resource occurrence and coal development potential maps of the Gillette East quadrangle, Campbell County, Wyoming: U.S. Geological Survey Open-File Report 79-42, 26 p., 15 pls., 3 tables.

44. IntraSearch, Inc., 1979, Coal resource occurrence and coal development potential maps of the Fortin Draw quadrangle, Campbell County, Wyoming: U.S. Geological Survey Open-File Report 79-43, 25 p., 20 pls., 3 tables.

45. IntraSearch, Inc., 1981, Coal rosource occurrence and coal development potential maps of the Juniper Draw quadrangle, Johnson County, Wyoming: U.S. Geslogical Survey Open-File Report 79-174, 33 p., 40 over-size sheets.

46. IntraSearch, Inc., 1981, Coal rosource occurrence and coal development pitential maps of the Laskie Draw quadrangle, Johnson and Campbell Counties, Wyoming: U.S. Geological Survey Open-File Report $79-175,35$ p., 45 over-size sheets.

47. IntraSearch, Inc., 1980, Coal rosource occurrence and coal development potential maps of the Morgan Draw quadrangle, Campbell County, Wyoming: U.S. Geological Survey Open-File Report. 79-44, 29 p., 45 over-size sheets.

48. IntraSearch, Inc., 1980, Coal rosource occurrence and coal development potential maps of the Scott Dam quadrangle, Campbell County, Wyoming: U.S. Geological Survey Open-File Report 79-45, 29 p., 35 over-size sheets.

49. IntraSearch, Inc., 1980, Coal rosource occurrence and coal development potential maps of the Four Bar $J$ Ranch quadrangle, Campbell County, Wyoming: U.S. Geological Survey Open-File Report. 79-46, 32 p., 55 over-size sheets.

50. IntraSearch, Inc., 1980, Coal risource occurrence and coal development potential maps of the Appel Butte quadrangle, Campbell County, Wyoming: U.S. Geological Survey Open-File Repor $\uparrow$. 79-47, 29 p., 31 over-size sheets. 
51. IntraSearch, Inc., 1979, Coal resource occurrence and coal development potential maps of The Gap quadrangle, Campbell County, Wyoming: U.S. Geological Survey Open-File Report 79-48, 27 p., 20 pls., 3 tables.

52. IntraSearch, Inc., 1979, Coal resource occurrence and coal development potential maps of the Coyote Draw quadrangle, Campbell County, Wyoming: U.S. Geological Survey Open-File Report 79-49, 31 p., 25 pls., 3 tables.

53. IntraSearch, Inc., 1980, Coal resource occurrence and coal development potential maps of the Bowman Flat quadrangle, Johnson County, Wyoming: U.S. Geological Survey Open-File Report 79-176, 32 p., 40 over-size sheets.

54. IntraSearch, Inc., 1980, Coal resource occurrence and coal development potential maps of the Negro Butte quadrangle, Johnson and Campbell Counties, Wyoming: U.S. Geological Survey Open-File Report 79-177, 39 p., 41 over-size sheets.

55. IntraSearch, Inc., 1980, Coal resource occurrence and coal development potential maps of the Bogie Draw quadrangle, Campbell County, Wyoming: U.S. Geological Survey Open-File Report 79-50, 29 p., 35 over-size sheets.

56. IntraSearch, Inc., 1980, Coal resource occurrence and coal development potential maps of the Double Tanks quadrangle, Campbell County, Wyoming: U.S. Geological Survey Open-File Report 79-51, 35 p., 35 over-size sheets.

57. IntraSearch, Inc., 1980, Coal resource occurrence and coal development potential maps of the Pleasantdale quadrangle, Campbell County, Wyoming: U.S. Geological Survey Open-File Report 79-52, 31 p., 40 over-size sheets.

58. IntraSearch, Inc., 1980, Coal resource occurrence and coal development potential maps of the Scaper Reservoir quadrangle, Campbell County, Wyoming: U.S. Geological Survey Open-File Report 79-53, 28 p., 30 over-size sheets.

59. IntraSearch, Inc., 1979, Coal resource occurrence and coal development potential maps of The Gap SW quadrangle, Campbell County, Wyoming: U.S. Geological Survey Open-File Report 79-54, 34 p., 14 pls., 3 figs. 3 tables.

60. IntraSearch, Inc., 1979, Coal resource occurrence and coal development potential maps of the Saddle Horse Butte quadrangle, Campbell County, Wyoming: U.S. Geological Survey Open-File Report 79-55, 26 p., 14 pls., 3 tables.

61. IntraSearch, Inc., 1979, Coal resource occurrence and coal development potential maps of the Whitetail Creek quadrangle, Campbell County, Wyoming: U.S.
Geological Survey Open-File Repo"t 79-56, 16 p., 3 pls.

62. IntraSearch, Inc., 1981, Coal resource occurrence and coal development potential maps of the Hoe Ranch quadrangle, Johnson County, Wyoming: U.S. Geologicel Survey Open-File Report 79-178, 31 p., 39 oversize sheets.

63. IntraSearch, Inc., 1981, Coal resource occurrence and coal development potential maps of the Nipple quadrangle, Jornson and Campbell Counties, Wyoming: U.S. Geological Survey Open-File Report 79-179, 34 p., 55 over-size sheets.

64. IntraSearch, Inc., 1980, Coal resource occurrence and coal development potential maps of the Fats Draw quadrangle, Campbell County, Wyoming: U.S. Geological Survey Open-File Repont 79-57, 29 p., 30 over-size sheets.

65. IntraSearch, Inc., 1980, Coal resource occurrence and coal development potential maps of the NE quarter of the Sqvageton 15-minute quadrangle, Campbell County, Wyoming: U.S. Geological Survey OpenFile Report 79-58, 36 p., 30 over-size sheets.

66. IntraSearch, Inc., 1980, Coal resource occurrence and coal development potential maps of the NW quarter of the North Star School 15-minute quadrangle, Campbell County, Wyoming: U.S. Geologicel Survey Open-File Report 79-59, 36 p., 40 over-size sheets.

67. IntraSearch, Inc., 1980, Coal resource occurrence and coal development potential maps of the NE quarter of the North Star School 15-minute quadrangle, Campbell County, Wyoming: U.S. Geologicel Survey Open-File Report 79-60, 30 p., 30 over-size sheets.

68. IntraSearch, Inc., 1979, Coal resource occurrence and coal development potential maps of the Eagle Rock quadrangle, Campbell County, Wyoming: U.S. Geological Survey Open-File Report 79-61, 34 p., 25 pls., 3 figs., 3 tables.

69. IntraSearch, Inc., 1979, Coal resource occurrence and coal development potential maps of the Neil Butte quadrangle, Campbell County, Wyoming: U.S. Geological Survey Open-File Report 79-62, 27 p., 20 pls., 3 tables.

70. IntraSearch, Inc., 1979, Coal resource occurrence and coal development potential maps of the Rough Creek quadrangle, Campbell County, Wyoming: U.S. Geological Survey Open-File Report 79-63, 25 p., 9 pls., 1 table.

71. IntraSearch, Inc., 1981, Coal resource occurrence and coal development potential maps of the Fort Reno SE quadrangle, Johnson and Campbell Counties, Vyoming: U.S. Geological Survey Open-File. Report 
79-180, 31 p., 45 over-size sheets.

72. IntraSearch, Inc., 1980, Coal resource occurrence and coal development potential maps of the North Butte quadrangle, Campbell County, Wyoming: U.S. Geological Survey Open-File Report 79-64, 24 p., 23 over-size sheets.

73. IntraSearch, Inc., 1980, Coal resource occurrence and coal development potential maps of the Savageton quadrangle, Campbell County, Wyoming: U.S. Geological Survey Open-File Report 79-65, 27 p., 26 over-size sheets.

74. IntraSearch, Inc., 1980, Coal resource occurrence and coal development potential maps of the SW quarter of the North Star School 15-minute quadrangle, Campbell County, Wyoming: U.S. Geological Survey Open-File Report 79-66, 31 p., 40 over-size sheets.

75. IntraSearch, Inc., 1980, Coal resource occurrence and coal development potential maps of the SE quarter of the North Star School 15-minute quadrangle, Campbell County, Wyoming: U.S. Geological Survey Open-File Report 79-67, 31 p., 37 over-size sheets.

76. IntraSearch, Inc., 1979, Coal resource occurrence and coal development potential maps of the Reno Junction quadrangle, Campbell County, Wyoming: U.S. Geological Survey Open-File Report 79-68, 32 p., 29 pls., 3 tables.

77. IntraSearch, Inc., 1979, Coal resource occurrence and coal development potential maps of the Hilight quadrangle, Campbell County, Wyoming: U.S. Geological Survey Open-File Report 79-69, 30 p., 21 pls., 3 tables.

78. IntraSearch, Inc., 1979, Coal resource occurrence and coal development potential maps of the Open A Ranch quadrangle, Campbell County, Wyoming: U.S. Geological Survey Open-File Report 79-70, 29 p., 19 pls., 3 tables.

79. IntraSearch, Inc., 1980, Coal resource occurrence and coal development potential maps of the Rolling Pin Ranch quadrangle, Campbell County, Wyoming: U.S. Geological Survey Open-File Report 79-71, 23 p., 19 over-size sheets.

80. IntraSearch, Inc., 1980, Coal resource occurrence and coal development potential maps of the South Butte quadrangle, Campbell County, Wyoming: U.S. Geological Survey Open-File Report 79-72, 28 p., 25 over-size sheets.

81. IntraSearch, Inc., 1980, Coal resource occurrence and coal development potential maps of the NW $1 / 4$ of the Turnercrest quadrangle, Campbell County, Wyoming: U.S. Geological Survey Open-File Report 79-73, 26 p., 25 over-size sheets.

82. IntraSearch, Inc., 1979, Coal resource occurrence and coal development potential maps of the NE $1 / 4$ of Turnercrest 15minute quadrangle, Campbell County, Wyoming: U.S. Geological Survey OpenFile Report $79-74,30$ p., 35 over-size sheets.

83. IntraSearch, Inc., 1980, Coal resource occurrence and coal development potential maps of the Little Thunder Reservoir quadrangle, Campbell County, Wyoming: U.S. Geological Survey Open-File Report 79-75, 29 p., 29 over-size sheets.

84. IntraSearch, Inc., 1979, Coal resource occurrence and coal development potential maps of the Reno Reservoir quadrangle, Campbell County, Wyoming: U.S. Geological Survey Open-File Report 79-76, 27 p., 14 pls., 3 tables.

85. IntraSearch, Inc., 1979, Coal rэsource occurrence and coal development potential maps of the Piney Canyon NW quadrangle, Campbell County, Wyoming: U.S. Geological Survey Open-File Report 79-77, 27 p., 14 over-size sheets.

86. IntraSearch, Inc., 1980, Coal rosource occurrence and coal development potential maps of Artesian Draw quadrangle, Campbell County, Wyoming: U.S. Geological Survey Open-File Report 79-308, 23 p., 9 over-size sheets.

87. Wunder, J.M., 1980, Coal resource occ גrrence and coal development potential maps of the Pine Tree quadrangle, Campbell County, Wyoming: U.S. Geological Survey OpenFile Report $80-42,25$ p., 16 over-size sheets.

88. IntraSearch, Inc., 1979, Coal resource occurrence and coal development potential maps of the SW $1 / 4$ of Turnercrest 15minute quadrangle, Campbell County, Wyoming: U.S. Geological Survey OpenFile Report 79-309, 26 p., 24 over-size sheets.

89. IntraSearch, Inc., 1980, Coal resource occurrence and coal development potential maps of the SE quarter of the Turrercrest 15-minute quadrangle, Campbell County, Wyoming: U.S. Geological Survey OpenFile Report 79-310, 30 p., 34 orer-size sheets.

90. IntraSearch, Inc., 1979, Coal rosource occurrence and coal development potential maps of the Teckla SW quadrangle, Campbell County, Wyoming: U.S. Geological Survey Open-File Report 79-311, 27 p., 19 pls, 3 tables.

91. IntraSearch, Inc., 1979, Coal resource occurrence and coal development potential maps of the Teckla quadrangle, Campbell County, Wyoming: U.S. Geological Survey Open-File Report 79-312, 28 p., 15 pls., 3 tables.

92. IntraSearch, Inc., 1979, Coal resource occurrence and coal development potential 
maps of the Piney Canyon $\mathrm{SW}$ quadrangle, Campbell County, Wyoming: U.S. Geological Survey Open-File Report 79-313, 27 p. 14 pls., 3 tables.

93. IntraSearch, Inc., 1979, Coal resource occurrence and coal development potential maps of the NE 1/4 of Edgerton 15-minute quadrangle, Natrona, Converse, Johnson, and Campbell Counties, Wyoming: U.S. Geological Survey Open-File Report 79-314, 14 p., 3 over-size sheets.

94. IntraSearch, Inc., 1980, Coal resource occurrence and coal development potential maps of the NW quarter of the Ross 15minute quadrangle, Converse and Campbell Counties, Wyoming: U.S. Geological Survey Open-File Report 79-315, 22 p., 8 over-size sheets.

95. IntraSearch, Inc., 1980, Coal resource occurrence and coal development potential maps of the NE quarter of the Ross 15minute quadrangle, Converse and Campbell Counties, Wyoming: U.S. Geological Survey Open-File Report 79-181, 31 p., 24 oversize sheets.

96. IntraSearch, Inc., 1980, Coal resource occurrence and coal development potential maps of the $\mathrm{NW}$ quarter of the Coal Draw 15-minute quadrangle, Converse and Campbell Counties, Wyoming: U.S. Geological Survey Open-File Report 79-316, 26 p., 24 over-size sheets.

97. IntraSearch, Inc., 1980, Coal resource occurrence and coal development potential maps of the NE quarter of the Coal Draw 15-minute quadrangle, Converse and Campbell Counties, Wyoming: U.S. Geological Survey Open-File Report 79-317, 30 p., 32 over-size sheets.

98. IntraSearch, Inc., 1980, Coal resource occurrence and coal development potential maps of the NW quarter of the Betty Reservoir 15-minute quadrangle, Converse and Campbell Counties, Wyoming: U.S. Geological Survey Open-File Report 79-318, 28 p., 19 over-size sheets.

99. IntraSearch, Inc., 1979, Coal resource occurrence and coal development potential maps of the NE $1 / 4$ of Betty Reservoir 15minute quadrangle, Converse and Campbell Counties, Wyoming: U.S. Geological Survey Open-File Report 79-319, 26 p., 19 oversize sheets.

100. IntraSearch, Inc., 1979, Coal resource occurrence and coal development potential maps of the Coal Bank Draw quadrangle, Converse and Campbell Counties, Wyoming: U.S. Geological Survey OpenFile Report 79-320, 33 p., 19 over-size sheets.

101. IntraSearch, Inc., 1979, Coal resource occurrence and coal development potential maps of the Fiddleback Ranch quadrangle, Campbell, Converse, and Weston Counties,
Wyoming: U.S. Geological Survey OpenFile Report 79-321, 14 p., 3 pls.

102. IntraSearch, Inc., 1979, Coal resource occurrence and coal development potential maps of the Lance Creek $2 \mathrm{NW}$ quadrangle, Converse and Niobrara Counties, Wyoming: U.S. Geological Survey OpenFile Report 79-322, 14 p., 3 over-size sheets.

103. IntraSearch, Inc., 1979, Coal resource occurrence and coal development potential maps of the SW $1 / 4$ of Ross 15-minute quadrangle, Converse County, ryoming: U.S. Geological Survey Open-File Report 79-323, 12 p., 3 over-size sheets.

104. IntraSearch, Inc., 1980, Coal resource occurrence and coal development potential maps of the SE quarter of the Ross 15minute quadrangle, Converse County, Wyoming: U.S. Geological Surve.y OpenFile Report 79-324, 27 p., 24 over-size sheets.

105. IntraSearch, Inc., 1980, Coal resource occurrence and coal development potential maps of the SW quarter of the Coal Draw 15-minute quadrangle, Converse County, Wyoming: U.S. Geological Survey OpenFile Report $79-325,26$ p., 24 over-size sheets.

106. IntraSearch, Inc., 1980, Coal resource occurrence and coal development potential maps of the SE quarter of the Conal Draw 15-minute quadrangle, Converse County, Wyoming: U.S. Geological Survey OpenFile Report $79-451,26$ p., 20 over-size sheets.

107. IntraSearch, Inc., 1979, Coal resource occurrence and coal development potential maps of the SW 1/4 of Betty Rese"voir 15minute quadrangle, Converse County, Wyoming: U.S. Geological Survey OpenFile Report 79-452, 22 p., 8 over-size sheets.

108. IntraSearch, Inc., 1979, Coal resource occurrence and coal development potential maps of the Tin Can Lake quadrangle, Converse County, Wyoming: U.S. Geological Survey Open-File Report 79-453, 25 p., 9 over-size sheets.

109. IntraSearch, Inc., 1980, Coal resource occurrence and coal development potential maps of the Esau Spring quadrangle, Converse County, Wyoming: U.S. Geological Survey Open-File Report. 79-454, 26 p., 19 over-size sheets.

110. IntraSearch, Inc., 1979, Coal resource occurrence and coal development potential maps of the Lance Creek 2 SW quadrangle, Converse and Niobrara Counties, Wyoming: U.S. Geological Survey OpenFile Report $79-455,27$ p., 9 over-size sheets.

111. IntraSearch, Inc., 1980, Coal resource occurrence and coal development potential 
maps of the NW quarter of the Fifty-Five Ranch 15-minute quadrangle, Converse County, Wyoming: U.S. Geological Survey Open-File Report 79-456, 23 p., 14 oversize sheets.

112. IntraSearch, Inc., 1980, Coal resource occurrence and coal development potential maps of the NE quarter of the Fifty-Five Ranch 15-minute quadrangle, Converse County, Wyoming: U.S. Geological Survey Open-File Report 79-457, 26 p., 19 oversize sheets.

113. IntraSearch, Inc., 1980, Coal resource occurrence and coal development potential maps of the $\mathrm{NW}$ quarter of the Highland Flats 15-minute quadrangle, Converse County, Wyoming: U.S. Geological Survey Open-File Report 79-458, 26 p., 24 oversize sheets.

114. IntraSearch, Inc., 1980, Coal resource occurrence and coal development potential maps of the NE quarter of the Highland Flats 15-minute quadrangle, Converse County, Wyoming: U.S. Geological Survey Open-File Report 79-459, 22 p., 8 over-size sheets.

115. IntraSearch, Inc., 1979, Coal resource occurrence and coal development potential maps for the Bill $4 \mathrm{NW}$ quadrangle, Converse County, Wyoming: U.S. Geological Survey Open-File Report 79-460, 21 p., 9 pls., 1 table.

116. IntraSearch, Inc., 1979, Coal resource occurrence and coal development potential maps of the Bill $4 \mathrm{NE}$ quadrangle, Converse County, Wyoming: U.S. Geological Survey Open-File Report $79-461,22$ p., 19 oversize sheets.

117. IntraSearch, Inc., 1979, Coal resource occurrence and coal development potential maps of the Lance Creek $3 \mathrm{NW}$ quadrangle, Converse and Niobrara Counties, Wyoming: U.S. Geological Survey OpenFile Report 79-462, 36 p., 4 over-size sheets.

118. IntraSearch, Inc., 1979, Coal resource occurrence and coal development potential maps of the SW 1/4 of Fifty-Five Ranch 15minute quadrangle, Converse County, Wyoming: U.S. Geological Survey OpenFile Report 79-463, 12 p., 3 over-size sheets.

119. IntraSearch, Inc., 1980, Coal resource occurrence and coal development potential maps of the SE quarter of the Fifty-Five Ranch 15-minute quadrangle, Converse County, Wyoming: U.S. Geological Survey Open-File Report 79-464, 28 p., 24 oversize sheets.

120. IntraSearch, Inc., 1980, Coal resource occurrence and coal development potential maps of the $\mathrm{SW}$ quarter of the Highland Flats 15-minute quadrangle, Converse County, Wyoming: U.S. Geological Survey
Open-File Report 79-465, 25 p., 14 oversize sheets.

121. IntraSearch, Inc., 1980, Coal resource occurrence and coal development pctential maps of the SW quarter of the Eill 15minute quadrangle, Converse County, Wyoming: U.S. Geological Survey OpenFile Report 79-466, 24 p., 9 over-size sheets.

122. IntraSearch, Inc., 1979, Coal resource occurrence and coal development pctential maps of the Bill $4 \mathrm{SW}$ quadrangle, Converse County, Wyoming: U.S. Geological Survey Open-File Report 79-467, 13 p., 3 pls

123. IntraSearch, Inc., 1979, Coal resource occurrence and coal development pctential maps of the Lance Creek $3 \mathrm{SW}$ quadrangle, Converse and Niobrara Ccunties, Wyoming: U.S. Geological Survey OpenFile Report 79-468, 22 p., 14 over-size sheets.

124. IntraSearch, Inc., 1980, Coal resource occurrence and coal development pctential maps of the Campbell Hill quadrangle, Converse and Natrona Counties, Wyoming: U.S. Geological Survey Open-File Report $79-469,21$ p., 8 over-size sheets.

125. IntraSearch, Inc., 1980, Coal resource occurrence and coal development pctential maps of the Glenrock $\mathrm{NW}$ quadrangle, Converse County, Wyoming: U.S. Geological Survey Open-File Report 79-470, 19 p., 8 over-size sheets.

126. IntraSearch, Inc., 1980, Coal resource occurrence and coal development pctential maps of the Hylton Ranch quadmangle, Converse County, Wyoming: U.S. Geological Survey Open-File Report 79-471, 29 p., 3 over-size sheets.

127. IntraSearch, Inc., 1979, Coal resource occurrence and coal development pctential maps of the Walker Creek School quadrangle, Converse County, Wyoming: U.S. Geological Survey Open-File Report 79-472, 14 p., 3 pls.

128. IntraSearch, Inc., 1979, Coal resource occurrence and coal development pctential maps of the Lost Springs NW quadrangle, Converse and Niobrara Ccunties, Wyoming: U.S. Geological Survey OpenFile Report 79-473, 30 p., 3 pls., 4 figs., 1 table.

129. IntraSearch, Inc., 1979, Coal resource occurrence and coal development pctential maps of the Cooley Draw quadrangle, Niobrara County, Wyoming: U.S. Geological Survey Open-File Report 79-474, 13 p., 3 pls.

130. IntraSearch, Inc., 1979, Coal resource occurrence and coal development pctential maps of the Parkerton quadrangle, Converse County, Wyoming: U.S. Geological Survey Open-File Report 79-475, 13 p., 3 over-size sheets. 
131. IntraSearch, Inc., 1979, Coal resource occurrence and coal development potential maps of the Glenrock quadrangle, Converse County, Wyoming: U.S. Geological Survey Open-File Report 79-476, 27 p., 2 over-size sheets.

132. IntraSearch, Inc., 1979, Coal resource occurrence and coal development potential maps of the Careyhurst quadrangle, Converse County, Wyoming: U.S. Geological Survey Open-File Report 79-477, 13 p., 3 over-size sheets.

133. IntraSearch, Inc., 1979, Coal resource occurrence and coal development potential maps of the Orpha quadrangle, Converse County, Wyoming: U.S. Geological Survey Open-File Report 79-478, 13 p., 3 over-size sheets.

134. IntraSearch, Inc., 1980, Coal resource occurrence and coal development potential maps of the Park quadrangle, Converse County, Wyoming: U.S. Geological Survey Open-File Report 79-479, 25 p., 10 oversize sheets.

135. Intra Search, Inc,, 1980, Coal resource occurrence and coal development potential maps of the Lost Springs quadrangle, Converse and Niobrara Counties, Wyoming: U.S. Geological Survey OpenFile Report $79-480,28$ p., 3 over-size sheets.

A. Mapel, W. J., 1976, Geologic map and coal sections of the Bar $N$ Draw quadrangle, Wyoming and Montana: U.S. Geological Survey Miscellaneous Field Studies Map
MF-763, 2 sheets.

B. Culbertson, W.C., 1975, Preliminary geologic map and coal sections of the r"yarno quadrangle, Sheridan County, Wyrming: U.S. Geological Survey Miscellaneous Field Studies Map MF-723, 2 sheets.

C. Culbertson, W.C., and Klett, M.C., 1975, Preliminary geologic map and coal sections of the Jones Draw quadrangle, St aridan County, Wyoming: U.S. Geological Survey Miscellaneous Field Studies Map MF-726, 1 sheet.

D. Culbertson, W.C., and Klett, M.C., 1975, Preliminary geologic map and coal sections of the SR Springs quadrangle, Sheridan County, Wyoming: U.S. Geological Survey Miscellaneous Field Studies Map MF-727, 2 sheets.

E. Mapel, W.J., and Malahy, M.D., 1976, Geologic map and coal sections of the Buffelo Run Creek quadrangle, Sheridan County, Wyoming: U.S. Geological Survey Miscellaneous Field Studies Map MF-792, 1 sheet.

F. Mapel, W.J., and Dean, B.W., 1976, Geologic map and coal sections of the Verona quadrangle, Sheridan County, Wyoming: U.S. Geological Survey Miscellaneous Field Studies Map MF-762, 2 sheets.

G. Mapel, W.J., and Dean, B.W., 1976, Preliminary geologic map and coal sections of the Ulm quadrangle, Sheridan County, Wyoming: U.S. Geological Survey Miscellaneous Field Studies Map Mr-731, 2 sheets. 
